\title{
Asymmetric Synthesis of $\beta$-Lactams via the Zinc-Mediated Glycine Ester Enolate-Imine Condensation Reaction Using $\alpha$-Amino Esters as the Chiral Auxiliary
}

\author{
Hendrik L. van Maanen, ${ }^{\dagger}$ Henk Kleijn, ${ }^{\dagger}$ Johann T. B. H. Jastrzebski, ${ }^{\dagger}$ Jan Verweij, ${ }^{\dagger}$ \\ Antonius P. G. Kieboom, ${ }^{\ddagger}$ and Gerard van Koten ${ }^{*,}$ \\ Department of Metal-Mediated Synthesis, Debye Institute, Utrecht University, \\ Padualaan 8, $3584 \mathrm{CH}$ Utrecht, The Netherlands and Gist-brocades, R\&D, P. O. Box 1 , \\ 2600 MA Delft, The Netherlands
}

Received January $18,1995^{\otimes}$

\begin{abstract}
Imine esters of glycine, $(R)$-phenylglycine, $(R)$-(1,4-cyclohexadienyl)glycine and $(S)$-valine have been employed in the ester enolate-imine condensation via double activation with $\mathrm{ZnCl}_{2}$. The reaction of the chlorozinc enolate (1b) of ethyl (2,2,5,5-tetramethyl-1-aza-2,5-disilacyclopentyl)acetate with $(R)$-methyl $N$-benzylidene-2-phenylglycinate (2a) afforded the trans- $\beta$-lactam 3a in $79 \%$ yield with excellent asymmetric induction (de $>97 \%$ ). Other imine esters also afforded trans- $\beta$-lactams diastereoselectively, albeit in lower conversions (37-70\%). Methyl (S)-2-[N-[3-(trimethylsilyl)-2propyn-1-ylidene]amino]-3-methylbutanoate (2e) afforded a mixture of four diastereoisomers (68\% conversion). The products were isolated as 3-phthalimido $\beta$-lactams $5 \mathbf{b}-\mathbf{e}$ and as $3-[($ methoxycarbonyl)amino]- $\beta$-lactam $6 \mathbf{b}$. The reactivity of the zinc enolates and the diastereoselectivity of the reactions are discussed in terms of the coordination of the imine esters to $\mathrm{ZnCl}_{2}$ (template effect) and the stability and aggregation equilibria of the zinc enolates.
\end{abstract}

\section{Introduction}

Following the discovery that the $\beta$-lactam function was the source of the unprecedented antibacterial activity of penicillin, several decades of biological and chemical research have resulted in the discovery of new classes of natural $\beta$-lactam antibiotics ${ }^{1}$ (e.g. cephalosporins, thienamycins, and nocardicins) and the development of new routes to synthetic $\beta$-lactams (monobactams, carbacephems, carbapenems). ${ }^{2}$ The first successful synthetic approach was the base-induced condensation of an activated carboxylic acid (usually an acid chloride) and an imine (Staudinger reaction), ${ }^{3,4}$ The diastereoselectivity of this reaction, which primarily affords cis- $\beta$-lactams, ${ }^{4}$ is reagentcontrolled. The development of enolate chemistry opened up a second route to $\beta$-lactams, via the condensation reaction of metal enolates with imines. ${ }^{5}$ The diastereoselectivity of this reaction is controlled by the metal, ${ }^{6-12}$

\footnotetext{
+ Utrecht University.

¥ Gist-brocades.

ه Abstract published in Advance ACS Abstracts, June 1, 1995

(1) (a) Chemistry and biology of $\beta$-lactam antibiotics; Morin, R. B.; Gorman, M., Ed.; Acad. Press: New York, 1982; Vol. 1-3. (b) Dürckheimer, W.; Blumbach, J.; Latrell, R.; Scheunemann, K. H. Angew. Chem. 1985, 97, 183-205. (c) Narisada, M. Pure Appl. Chem. 1987, 59, 459-467. (d) The Organic Chemistry of $\beta$-Lactams; Georg, G. I., Ed.; VCH Publishers: New York, 1992; pp 257-367.

(2) For a recent reviews, see: (a) Nagahara, T.; Kametani, T. Heterocycles 1987, 25, 729-806. (b) Stachulski, A. V. Amino Acids Prot. 1988, 19, 251-289. (c) Stachulski, A. V. Amino Acids Prot. 1989, 20, 249-296. (d) Frydrych, C. H.; Amino Acids Prot. 1991, 22, 294-342. (e) Frydrych, C. H. Amino Acids Prot. 1992, 23, 249-296. (f) Frydrych C. H. Amino Acids Prot. 1993, 24, 245-286.

(3) Sheehan, J. C., Ryan, J. J. J. Am. Chem. Soc. 1951, 73, 12041207

(4) (a) Govindachari, T. R.; Chinnasamy, P.; Raewari, S.; Candrasekaran, S.; Premila, M.S.; Nagarajan, K. Pai, R. Heterocycles 1984 22, 585. (b) Evans, D. A.; Sjögren, E. B. Tetrahedron Lett. 1985, 26, 3783-3786. (c) Cooper, R. D. G.; Daugherty, B. W.; Boyd, D. B. Pure Appl. Chem. 1987, 59, 485-492. (d) Shandu, J. S.; Sain, B. Heterocycles 1987, 26, 777. (e) Palomo, C.; Cossio, F. P.; Cuevas, C.; Lecea, B Mielgo, A.; Roman, P.; Luque, A.; Martinez-Ripoll, M. J. Am. Chem. Soc. 1992, 114, 9360-9369.
}

giving access to either cis- or trans- $\beta$-lactams. The excellent results in asymmetric syntheses of $\beta$-lactams have recently resulted in the application of $\beta$-lactams as synthons for acyclic compounds. ${ }^{13}$

Most $\beta$-lactam antibiotics contain a carboxylic acid or ester substituted side chain on the nitrogen atom. Usually, the introduction of this functionality is achieved

(5) For recent reviews, see: (a) Hart, D. J.; Ha, D-C. Chem. Rev 1989, 89, 1447-1465. (b) Brown, M. J. Heterocycles 1989, 29, 22252244. (c) Van der Steen, F. H.; Van Koten, G. Tetrahedron 1991, 47, 7503-7524.

(6) Zinc: (a) Van der Steen, F. H.; Kleijn, H.; Spek, A. L.; Van Koten, G. J. Chem. Soc., Chem. Commun. 1990, 503-504. (b) Van der Steen, F. H,; Kleijn, H.; Jastrzebski, J. T. B. H.; Van Koten, G. J. Org.Chem. 1991, 56, 5147-5158. (c) Van der Steen, F. H.; Van Mier, G. P. M.; Spek, A. L.; Kroon, J.; Van Koten, G. J. Am. Chem. Soc. 1991, 113, 5742-5750. (d) Van der Steen, F. H.; Kleijn, H.; Britovsek, G. J. P.; Jastrzebski, J. T. B. H.; Van Koten, G. J. Org. Chem. 1992, 57, 39063916. (e) Van der Steen, F. H.; Boersma, J.; Spek, A. L.; Van Koten, G. Organometallics 1991, 10, 2467-2480. (f) Van Maanen, H. L.; Jastrzebski, J. T. B. H.; Verweij, J.; Kieboom, A. P. G.; Spek, A.L.; Van Koten, G. Tetrahedron Asymm. 1993, 4, 1441-1444. (g) In this respect it should be noted that zinc-mediated condensations of esters with imines under Reformatsky conditions have been reported earlier; 6 h, (h) Gilman, H.; Speeter, M. J. J. Am. Chem. Soc. 1943, 65, 2255. (i) Luche, J. L.; Kagan, H. B.; Tsoucaris, G.; De Rango, C.; Zelwer, C. Tetrahedron 1968, 24, 1275.

(7) Lithium: (a) Gluchowski, C.; Cooper, L.; Bergbreiter, D. E. Newcomb, M. J. Org. Chem. 1980, 45, 3413-3416. (b) Burnett, D. A.; Hart, D. J.; Li, J. J. Org. Chem. 1986, 51, 1929-1930. (c) Alcaide, B.; Gómez, A.; Plumet, J.; Rodriguez-López, J. Tetrahedron 1989, 45, 2751-2762. (d) Ojima, I.; Habus, I. Tetrahedron Lett., 1990, 31, 42894292. (e) Brown, M. J.; Overman, L. E. J. Org. Chem. 1991, 56, 19331936. (f) Alcaide, B.; Martín-Cantalejo, Y.; Pérez-Castels, J.; RodríguezLópez, J.; Sierra, M. A. J. Org. Chem. 1992, 57, 5921-5931.

(8) Aluminum: (a) ref 6e. (b) Wada, M; Aiura, H.; Akiba, K.-Y Tetrahedron Lett. 1987, 28, 3377-3380.

(9) Tin'I: (a) Mukaiyama, T.; Suzuki, H.; Yamada, T. Chem. Lett. 1986, 915-918. (b) Yamada, T.; Suzuki, H.; Mukaiyama, T. Chem. Lett. 1987, 293-296. (c) Nagao, Y.; Dai, W.-M.; Ochiai, M. Tetrahedron Lett. 1988, 29, 6133-6136. (d) Annunziata, R.; Benaglia, M.; Cinquini, M.; Cozzi, F.; Raimondi, L. Tetrahedron 1994, 50, 5821-5828.

(10) Boron: (a) Otsuka, M.; Yoshida, M.; Kobayashi, S.; Ohno, M.; Umezawa, H.; Morishima, H. Tetrahedron Lett. 1981, 22, 2109. (b) Shibasaki, M.; Ishida, Y.; Iwasaki, G.; Iimori, T. J. Org. Chem. 1987, 52, 3489. (c) Corey, E. J.; Decicco, C. P.; Newbold, R. C. Tetrahedron Lett. 1991, 32, 5287 . 
starting from the $\mathrm{N}$-unsubstituted $\beta$-lactam. ${ }^{6 \mathrm{~d}, 14}$ The formation of $\beta$-lactam already containing the ester function would allow a short synthesis of valuable intermediates. We have previously demonstrated ${ }^{6 d}$ that the diastereoselectivity of the ester enolate-imine condensation reaction could best be controlled by the use of stereogenic imine-nitrogen substituents. Therefore, imine esters derived from chiral $\alpha$-amino acids (2-[N-alkylideneamino] esters) might be employed in this reaction to combine excellent stereocontrol with atom economy, because the chiral auxiliary is itself a part of the target molecule. Furthermore, $\alpha$-amino acids are readily available chiral starting materials, some of which are available in both enantiomers. The use of chiral $\alpha$-amino acids has already resulted in the asymmetric synthesis of several $\beta$-lactams via the Staudinger reaction. ${ }^{15-21}$ However, there are only a few examples of $\mathrm{C}-\mathrm{C}$ coupling reactions of metal enolates with imines derived from $\alpha$-amino acids. ${ }^{10 a, 22}$ The presence of an ester function may lead to complications, because enolates may react with the ester function ${ }^{23}$ or deprotonate the imine ester, depending on the relative $\mathrm{p} K_{\mathrm{a}}$-values (transfer enolization). Furthermore, lithium enolates react only with $N$-trimethylsilyl- or $N$-arylimines. ${ }^{12,24}$

We have previously reported ${ }^{6}$ that zinc enolates display a superior reactivity toward imines, reacting even with unreactive $N$-alkylimines. Therefore we investigated the reaction of the chlorozinc enolate of ethyl $(2,2,5,5-$ tetramethyl-1-aza-2,5-disilacyclopentyl)acetate ${ }^{25}$ with

(11) Titanium: (a) Cinquini, M.; Cozzi, F.; Cozzi, P. G.; Consolandi, E. Tetrahedron 1991, 41, 8767-8774. (b) Fujisawa, T.; Ukaji, Y.; Noro, T.; Date, K.; Shimizu, M. Tetrahedron Lett. 1991, 32, 7563-7566. (c) Shimizu, M.; Ukaji, Y.; Tanizaki, J.; Fujisawa, T. Chem. Lett. 1992, 1349-1352. (d) Annunziata, R.; Cinquini, M.; Cozzi, F.; Cozzi, P. G. Tetrahedron Lett. 1992, 33, 1113-1116. (e) Annunziata, R.; Cinquini, M.; Cozzi, F.; Cozzi, P. G. J. Org. Chem. 1992, 57, 4155-4162. (f) Fujisawa, T.; Ukaji, Y.; Noro, T.; Date, K.; Shimizu, M. Tetrahedron 1992, 48, 5629-5638. (g) Fujisawa, T.; Hayakawa, R.; Shimizu, M. Tetrahedron Lett. 1992, 33, 7903-7906. (h) Fujisawa, T.; Ichikawa M.; Ukaji, Y.; Shimizu, M. Tetrahedron Lett. 1993, 34, 1307-1310. (i) Annunziata, R.; Benaglia, M.; Cinquini, M.; Cozzi, F.; Raimondi, L. Tetrahedron Lett. 1993, 34, 6921-6924. (j) Annunziata, R.; Benaglia, M.: Cinquini, M.; Cozzi, F.; Raimondi, L. Tetrahedron 1994, 50, 94719486 .

(12) Zirconium: Iwasaki, G.; Shibasaki, M. Tetrahedron Lett. 1987, $28,3257-3260$

(13) For reviews, see: (a) Ojima, I.; Shimizu, N.; Qiu, X.; Chen, H. J. C.; Nakahashi. Bull. Soc. Chim. Fr. 1987, 649-658. (b) Manhas M. S.; Wagle, D. R.; Chiang, J.; Bose, A. K. Heterocycles 1988, 27, 1755-1802. (c) Palomo, C.; Cossio, F. P.; Cuevas, C.; Ontoria, J. M. Odriozola, J. M.; Munt, S. Bull. Soc. Chim. Belg. 1992, 101, 541-554. (14) Georg, G. I.; Kant, J.; Gill, H. S. J. Am. Chem. Soc. 1987, 109 , 1129-1135, and references cited therein.

(15) Glycine: (a) Manhas, M. S.; Bose, A. K.; Khajavi, M. S. Synthesis 1981, 209-211. (b) Cossio, F. P.; Lecea, B.; Palomo, C. J. Chem. Soc., Chem. Commun. 1987, 1743-1744.

(16) Alanine: Ojima, I.: Nakahashi, K.; Brandstadter, S. M.; Hatanaka, N. J. Am. Chem. Soc. 1987, 109, 1798-1805.

(17) Valine: (a) Bachi, M. D.; Ross-Petersen, K. J. J. Chem. Soc. Perkin Trans. 1 1975, 2525-2529. (b) Bachi, M. D.; Goldberg, O. J. Chem. Soc. Perkin Trans. 1 1972, 2332-2336.

(18) Phenylglycine and (4-hydroxyphenyl)glycine: (a) Kamiya, $\mathrm{T}$. Hashimoto, M.; Nakaguchi, O.; Oku, T. Tetrahedron 1979, 35, 323328. (b) Kamiya, T.; Oku, T.; Nakaguchi, O.; Takeno, H.; Hashimoto, M. Tetrahedron Lett. 1978, 19, 5119-5122. (c) Arrieta, A.; Lecea, B.;

Cossio, F. P.: Palomo, C. J. Org. Chem. 1988, 53, 3784-3791.

(19) Serine: Just, G.; Liak, T-J. Can. J. Chem. 1978, 56, 211-217. (20) Threonine: (a) Bose, A. J.; Manhas, M. S.; Van der Veen, J. M.; Bari, S. S.; Wagle, D. R. Tetrahedron 1992, 48, 4831-4844. (b) Bose, A. J.; Manhas, M. S.; Van der Veen, J. M.; Bari, S. S.; Wagle, D. R.; Hegde, V.; Krishnan, L. Tetrahedron Lett. 1985, 26, 33-36. (c) Tenneson, S. M.; Belleau, B. Can. J. Chem. 1980, 58, 1605-1607.

(21) Methionine: Bachi, M. D.; Ross-Petersen, K. J. J. Chem. Soc.

Chem. Commun. 1974, 12-13.

(22) Ojima, I.; Inaba, S-I. Tetrahedron Lett, 1980, 21, 2081-2084.

(23) Schäfer, J. P.; Bloomfield, J. J. Org. React. 1967, 15, 1-26.

(24) Ha, D.-C.; Hart, D. J.;Yang, T. K. J. Am. Chem. Soc. 1984, 106 , $4819-4822$.

\section{Scheme 1}

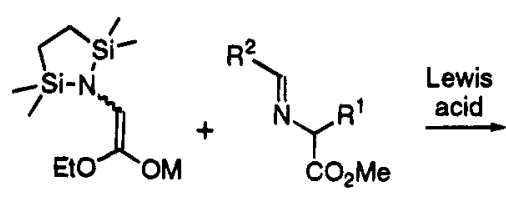

1a: $M=L i$

1b: $M=\mathrm{ZnCl}$

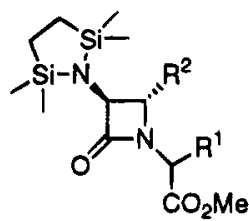

$3 a-0$

$$
\begin{aligned}
& \text { a : } R^{1}=R^{2}=C_{6} H_{5} \\
& \text { b : } R^{1}=1,4-c-C_{6} H_{7}, R^{2}=C_{6} H_{5} \\
& \text { c : } R^{1}=1,4-c-C_{6} H_{7}, R^{2}=4-C_{6} H_{4} O C_{3} \\
& \text { d }: R^{1}=i C_{3} H_{7}, R^{2}=4-C_{6} H_{4} O C H_{3} \\
& \text { : } R^{1}=i C_{3} H_{7}, R^{2}=C \equiv C-T M S \\
& f: R^{1}=H, R^{2}=C_{6} H_{5}
\end{aligned}
$$

imine esters derived from $\alpha$-imino acids. In a recent communication, ${ }^{6 f}$ we have demonstrated the use of $(R)$ 2-phenylglycine methyl ester as the chiral auxiliary in the zinc-mediated ester enolate-imine condensation route to trans- $\beta$-lactams. Activation of the imine ester by coordination to $\mathrm{ZnCl}_{2}$ prior to the $\mathrm{C}-\mathrm{C}$ coupling reaction was essential, resulting in excellent enantioselectivity (one diastereoisomer was obtained exclusively). In this way, we were able to construct the $\beta$-lactam ring and introduce the ester function in one step. Initially, aryl groups were chosen as the imine C-substituent, as the resulting imines are relatively stable and easily purified by crystallization. However, aryl substituents do not allow further functionalization of the $\mathrm{C} 4$ substituent of the 2-azetidinone. Hence, we have also investigated imine esters derived from (trimethylsilyl)propynal (affording a reactive substituent at $\mathrm{C} 4$ ) or from 1,4(cyclohexadienyl)glycine (giving a reactive 1-substituent). 4-(Trimethylsilyl)ethynyl- $\beta$-lactams have previously been functionalized via removal of the TMS-group and subsequent reduction, ${ }^{26 a}$ palladium-catalyzed methoxycarbonylation, ${ }^{26 \mathrm{~b}}$ or Hg-mediated hydrolysis. ${ }^{26 \mathrm{c}}$ The cyclohexadienyl group can be converted through ozonolysis, ${ }^{27}$ resulting in a $\beta$-keto aldehyde (via reductive workup) or $\beta$-keto ester (via oxidative workup).

\section{Results}

The lithium (1a) and chlorozinc enolates (1b) of the STABASE protected glycine ester were reacted with imine esters $2 \mathbf{a}-\mathbf{f}$ (Scheme 1), which were synthesized by condensation of the appropriate amino acid esters and aldehydes in the presence of a Lewis acid, i.e. $\mathrm{ZnCl}_{2}$. The results of the ester enolate-imine condensation reactions are presented in Table 1.

The chlorozinc enolate $1 \mathrm{~b}$ of ethyl [(2,2,5,5-tetramethyl1-aza-2,5-disilacyclopentyl)acetate was reacted with imine ester $2 \mathrm{a}\left(\mathbf{R}^{1}=\mathbf{R}^{2}=\mathrm{C}_{6} \mathrm{H}_{5}\right)$ via the previously optimized double activation procedure ${ }^{6 f}$ to give the trans$\beta$-lactam $3 a$ in $79 \%$ yield (entry 1 ). To obtain optically active products in this double activation reaction, it is necessary to generate the $\mathrm{ZnCl}_{2}$-complex of the imine ester 2a in situ in THF at $-78{ }^{\circ} \mathrm{C}$. Isolation of the

25) STABASE as protecting group: Djuric, S.; Venit, J.; Magnus, P. Tetrahedron Lett. 1981, 22, 1787-1790.

(26) (a) Chiba, T.; Nagatsuma, M.; Nakai, T. Chem. Lett. 1985 1343-1346. (b) Iimori, T.; Shibasaki, M. Tetrahedrom Lett. 1986, 27, 2149-2152. (c) Shibasaki, M.; Ishida, Y.; Iwasaki, G.; Iimori, T J. Org Chem. 1987, 52, 3488-3489.

(27) (a) Evans, D. A. Sjogren, E. Tetrahedron Lett. 1985, 26, 37873790. (b) Marshall, J. A.; Garofalo, A. W. J. Org. chem. 1993, 58, 36753680 
Table 1. $\beta$-lactams from the Condensation of Zinc Enolate $1 b$ and Imine Esters $2 a-f$

\begin{tabular}{|c|c|c|c|c|c|c|c|}
\hline entry & imine & $\mathrm{R}^{1}$ & $\mathrm{R}^{2}$ & Lewis acid & yield $(\%)^{\mathrm{a}}$ & $\operatorname{de}(\%)$ & isolated as \\
\hline 1 & $2 \mathbf{a}$ & $\mathrm{C}_{6} \mathrm{H}_{5}$ & $\mathrm{C}_{6} \mathrm{H}_{5}$ & $\mathrm{ZnCl}_{2}$ & 79 & $>98$ & 3-amino $\beta$-lactam $4 \mathrm{a}(44 \%)$ \\
\hline 2 & $2 \mathbf{a}$ & $\mathrm{C}_{6} \mathrm{H}_{5}$ & $\mathrm{C}_{6} \mathrm{H}_{5}$ & $\mathrm{ZnMe}_{2}$ & 62 & 76 & - \\
\hline 3 & $2 \mathbf{a}$ & $\mathrm{C}_{6} \mathrm{H}_{5}$ & $\mathrm{C}_{6} \mathrm{H}_{5}$ & $\mathrm{ZnCl}_{2}{ }^{\bar{b}}$ & 10 & & \\
\hline 4 & $\mathbf{2 a}$ & $\mathrm{C}_{6} \mathrm{H}_{5}$ & $\mathrm{C}_{6} \mathrm{H}_{5}$ & $\mathrm{ZnCl}_{2}{ }^{\mathrm{c}}$ & $\sim 50$ & $d$ & \\
\hline $5^{e}$ & $\mathbf{2 a}$ & $\mathrm{C}_{6} \mathrm{H}_{5}$ & $\mathrm{C}_{6} \mathrm{H}_{5}$ & $\mathrm{ZnCl}_{2}$ & 25 & & \\
\hline $6^{e}$ & $\mathbf{2 a}$ & $\mathrm{C}_{6} \mathrm{H}_{5}$ & $\mathrm{C}_{6} \mathrm{H}_{5}$ & $\mathrm{ZnMe}_{2}$ & 0 & & \\
\hline 7 & $\mathbf{2 b}$ & $c-\mathrm{C}_{6} \mathrm{H}_{7}$ & $\mathrm{C}_{6} \mathrm{H}_{5}$ & $\mathrm{ZnCl}_{2}$ & 70 & $>98$ & $\begin{array}{l}\text { phthalimide } \mathbf{5 b}(37 \%) \\
\text { methylcarbamate } \mathbf{6 b}(\mathbf{9} \%)\end{array}$ \\
\hline 8 & $\mathbf{2 c}$ & $c-\mathrm{C}_{6} \mathrm{H}_{7}$ & $4-\mathrm{C}_{6} \mathrm{H}_{4} \mathrm{OCH}_{3}$ & $\mathrm{ZnCl}_{2}$ & 58 & $>98$ & phthalimide $\mathbf{5} \mathbf{c}^{\mathrm{f}}$ \\
\hline 9 & $2 d$ & $i-\operatorname{Pr}$ & $4-\mathrm{C}_{6} \mathrm{H}_{4} \mathrm{OCH}_{3}$ & $\mathrm{ZnCl}_{2}$ & 37 & $>98$ & phthalimide 5d (25\%) \\
\hline 10 & $\mathbf{2 e}$ & $i-\operatorname{Pr}$ & $\mathrm{C} \equiv \mathrm{C}-\mathrm{TMS}$ & $\mathrm{ZnCl}_{2}$ & 68 & $g$ & phthalimide 5e $(21 \%$ h) \\
\hline 11 & $2 f$ & $\mathrm{H}$ & $\mathrm{C}_{6} \mathrm{H}_{5}$ & $\mathrm{ZnCl}_{2}$ & $i$ & & \\
\hline
\end{tabular}

${ }^{a}$ Based on recovered imine. ${ }^{b}$ Lewis acid added to zinc enolate instead of imine ester. ${ }^{c}$ One equivalent HMPA added. ${ }^{d}$ Mixture of cisand trans-3a 6:94. ${ }^{e}$ Reaction performed with lithium enolate 1a. $f$ Contaminated with a small amount of dehydrogenated product. $g$ All four diastereoisomers observed. ${ }^{h}$ 1:1 Mixture of trans-diastereoisomers. ${ }^{i}$ No $\beta$-lactam obtained.

\section{Scheme 2}

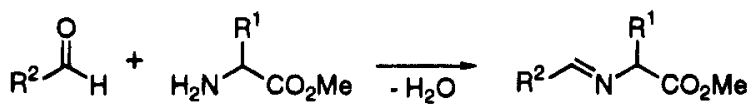

$$
\begin{aligned}
& \text { 2a-f } \\
& \text { a : } R^{1}=R^{2}=\mathrm{C}_{6} \mathrm{H}_{5} \\
& \text { b: } R^{1}=1,4-c-\mathrm{C}_{6} \mathrm{H}_{7}, \mathrm{R}^{2}=\mathrm{C}_{6} \mathrm{H}_{5} \\
& \text { c: } R^{1}=1,4-c-C_{6} \mathrm{H}_{7}, R^{2}=4-\mathrm{C}_{6} \mathrm{H}_{4} \mathrm{OCH}_{3} \\
& \text { d: } R^{1}=j \mathrm{C}_{3} \mathrm{H}_{7}, \mathrm{R}^{2}=4-\mathrm{C}_{6} \mathrm{H}_{4} \mathrm{OCH}_{3} \\
& \text { e: } \mathrm{R}^{1}=j \mathrm{C}_{3} \mathrm{H}_{7}, \mathrm{R}^{2}=\mathrm{C} \equiv \mathrm{C} \text {-TMS } \\
& f: R^{1}=H_{1} R^{2}=C_{6} H_{5}
\end{aligned}
$$

coordination complex prior to the reaction by stirring $\mathbf{2 a}$ with $\mathrm{ZnCl}_{2}$ in toluene $\left(50^{\circ} \mathrm{C}, 16 \mathrm{~h}\right)$ resulted in complete racemization of the imine ester. In this way, we generated the racemic $\beta$-lactam $3 \mathbf{a}^{6 f}$

Several variations of the reaction procedure were studied. (i) The use of $\mathrm{Me}_{2} \mathrm{Zn}$ instead of $\mathrm{ZnCl}_{2}$ as the Lewis acid resulted in a lower conversion and a decreased asymmetric induction (isolated yield: $62 \%$, de $76 \%$ ), and decomposition of the enolate occurred ${ }^{28}$ (entry 2). (ii) Addition of the second equivalent of $\mathrm{ZnCl}_{2}$ to the solution of the chlorozinc enolate $\mathbf{1 b}$ immediately before the addition of the uncomplexed imine ester $2 \mathrm{a}$ resulted in a very slow reaction and a conversion of only $10 \%$ after $24 \mathrm{~h}$ at $-30^{\circ} \mathrm{C}$ (entry 3 ). (iii) When the double activation reaction was performed in the presence of the strongly polar cosolvent HMPA, a small amount of cis-3a was formed (conversion $\sim 50 \%$, cis:trans $=6: 94$ ) (entry 4). (iv) The reaction of lithium enolate $1 \mathrm{a}$ with the $\mathrm{ZnCl}_{2}$ activated imine ester $\mathbf{2 a}$ is very slow and incomplete (entry 5). Notably, the product of this reaction is the same trans- $\beta$-lactam 3a that was obtained via the zincmediated route. Furthermore, lithium enolate 1a does not react with the $\mathrm{Me}_{2} \mathrm{Zn}$-coordinated imine ester $2 \mathrm{a}$ (entry 6).

According to the procedure of entry 1 , the chlorozinc enolate $1 \mathbf{b}$ of the STABASE protected glycine ester was reacted with the imine esters $2 \mathbf{b}-\mathbf{f}$ derived from $(R)-(1,4-$ cyclohexadienyl)glycine, ${ }^{29}(S)$-valine, or glycine (Scheme 2). Unlike the phenylglycine imine ester $2 \mathbf{a}$, the enantiomerically pure imine esters $2 \mathbf{b}-\mathbf{e}$ did not racemize in benzene solution containing $\mathrm{NEt}_{3}$, which was evidenced by a constant specific rotation.

(28) (a) Rathke, M. W. Sullivan, D. F. J. Am. Chem. Soc. 1973, 95, 3050-3052. (b) Sullivan, D. F.; Woodbury, R. P.; Rathke, M. W. J. Org. Chem. 1977, 42, 2038-2039.

(29) (1,4-Cyclohexadienyl)glycyl chloride hydrochloride is commercially available from Andeno, obtained via Birch reduction of $(R)$-2phenylglycine. Contaminated with circa $2 \%$ of $(R)$-2-phenylglycyl chloride.
Scheme 3

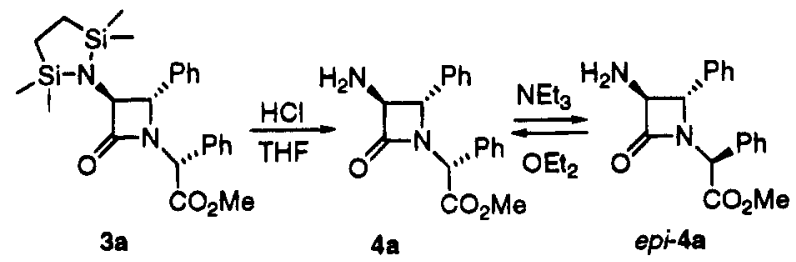

The reaction of the (1,4-cyclohexadienyl)glycine-derived imine esters $2 \mathbf{2 b , c}$ with zinc enolate $\mathbf{1 b}$ (Scheme 1) under the double activation conditions afforded trans- $\beta$-lactams $3 b, c$ diastereoselectively (Table 1 , entries 7 and 8 ), although the reactions did not go to completion. Starting from the $(S)$-valine imine ester $2 \mathbf{2 d}, \beta$-lactam 3d was formed diastereoselectively in $37 \%$ conversion based on recovered imine (entry 9). The condensation using imine ester 2e (entry $10, R^{2}=C \equiv C T M S$ ), which was obtained by condensation of $(S)$-valine methyl ester and 3-(trimethylsilyl)propynal as a $65: 35$ mixture of the $(E)$ - and (Z)-isomers, ${ }^{30}$ reacted with a surprisingly low diastereoselectivity. The $\mathrm{C}-\mathrm{C}$ coupling reaction with zinc enolate 1b under the double activation conditions afforded a mixture of all four diastereoisomers (conversion: 68\%; trans:cis $57: 43$, de trans $\sim$ de cis $=30 \%$ ) of $\beta$-lactam 3e. Finally, the glycine-derived imine ester $2 f$ failed to afford a $\beta$-lactam upon reaction with zinc enolate $\mathbf{1 b}$ (entry 11). ${ }^{31}$

Isolation of the products from the reaction mixtures was accomplished by a combination of chromatography and crystallization. Because the STABASE protecting group $^{25}$ is susceptible to hydrolysis during chromatography, the crude reaction products were deprotected $(\mathrm{HCl}$, THF, $30 \mathrm{~min}$ ) to the 3 -amino $\beta$-lactams $4 \mathbf{a}-\mathbf{e}$. The 3 -amino $\beta$-lactam $4 \mathbf{a}$ was found to epimerize under the mildly basic work-up conditions to epi-4a (Scheme 3), which was crystallized from $\mathrm{Et}_{2} \mathrm{O}$. Repeated epimerization/separation/crystallization afforded 1-(S)-[(methoxycarbonyl)phenylmethyl]-3(S)-amino-4(S)-phenyl-2-azeti-

(30) Generally aldimines have the $(E)$-configuration: (a) Fraser, $\mathrm{R}$ R.; Banville, J.; Akiyama, F.; Chuaqui-Offermanns, N. Can. J. Chem 1981, 59, 705-709. (b) De Kimpe, N.; Verhe, R.; De Buyck, L.; Schamp, N. Can. J. Chem. 1984, 62, 1812-1816.

(31) Instead of the expected $\beta$-lactam, the glycine imine ester 7 afforded an unexpected product, that was deprotected and crystallized from $\mathrm{Et}_{2} \mathrm{O}$, to afford cis-6-(ethoxycarbonyl)-5-phenylpiperazin-2-one in $23 \%$ yield (purity $94 \%$ ) as a white crystalline solid by crystallization from $\mathrm{Et}_{2} \mathrm{O}$, ${ }^{1} \mathrm{H}$ NMR $\left(\mathrm{CDCl}_{3}\right): \delta 7.3-7.4(\mathrm{~m}, 5 \mathrm{H}) ; 6.71(\mathrm{~s}, 1 \mathrm{H}) ; 4.37(\mathrm{~d}$, $J=7.8,1 \mathrm{H}) ; 4.15(\mathrm{~d}, J=7.8,1 \mathrm{H}) ; 4.05\left(\mathrm{ABX}_{3}, J=7.1,2 \mathrm{H}\right) ; 3.61(\mathrm{AB}$, $2 \mathrm{H}) ; 2.56$ (br s, $1 \mathrm{H}) ; 1.04(\mathrm{t}, J=7.1) .{ }^{13} \mathrm{C} \mathrm{NMR}\left(\mathrm{CDCl}_{3}\right): \delta 169.6,169.0$, $138.2,128.7,128.6,127.7,61.8,60.4,59.4,48.7,13.8$. IR $\left(\mathrm{KBr}, \mathrm{cm}^{-1}\right)$ : $1744\left(\mathrm{CO}_{2} \mathrm{Et}\right), 1669(\mathrm{NC}=\mathrm{O})$. MS: $\mathrm{m} / \mathrm{z}=248(50 \%), 118(100 \%)$. 


\section{Scheme 4}

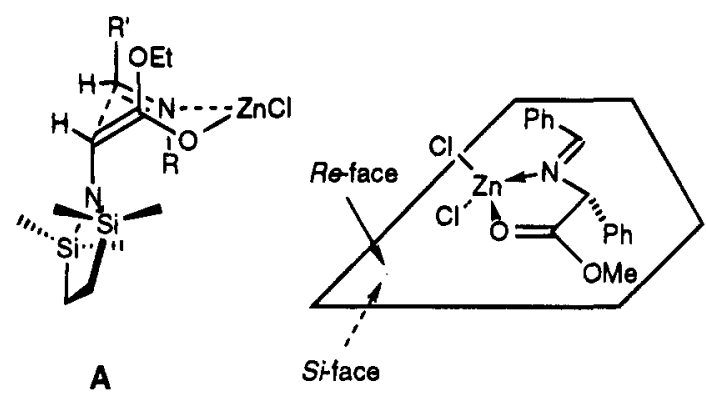

dinone (epi-4a), with $97 \%$ de. ${ }^{6 f}$ This sequence constitutes an asymmetric transformation of the second order. ${ }^{32}$ When this epimerization was carried out in $\mathrm{Et}_{2} \mathrm{O}$ containing $\mathrm{NEt}_{3}, \beta$-lactam epi-4a slowly precipitated at -30 ${ }^{\circ} \mathrm{C}$. Actually, the mildly basic conditions (3 equiv of $\mathrm{NEt}_{3}$, $\mathrm{rt}, 16 \mathrm{~h}$ ) used for STABASE-protection ${ }^{25}$ of the amino function of $4 a$ result in epimerization to a 44:56 mixture of $3 \mathbf{a}$ and epi-3a.

The unpurified 3-amino $\beta$-lactams $\mathbf{4 b}$-e were converted into the phtalimides $5 \mathbf{b}-\mathbf{e}$ by reaction with phtalic anhydride. ${ }^{33,34}$ The 3-phthalimido $\beta$-lactams $\mathbf{5 b}$-e were solids, which were purified by column chromatography $\left(\mathrm{SiO}_{2}, \mathrm{EtOAc/hexane}\right.$ 50:50) and subsequent crystallization from $\mathrm{Et}_{2} \mathrm{O}$. The 1,4-cyclohexadienyl-substituted $\beta$-lactam 5c was contaminated with the phenyl-substituted analogue as a result of dehydrogenation of the cyclohexadienyl function either during storage or workup. 3-Phthalimido $\beta$-lactam 5e was obtained as a 1:1 mixture of both trans-diastereoisomers in an overall yield of $27 \%$. As an alternative to phthalimide protection, $\mathbf{4 b}$ was also converted into the methyl carbamate $6 \mathbf{b}$, affording a solid compound that could be purified via column chromatography. However, the isolated yield of $\beta$-lactam $6 \mathbf{b}$ dropped to $9 \%$.

The purified $\beta$-lactams epi-4a, $5 \mathbf{b}, \mathbf{5 d}, 5 \mathbf{e}$, and $6 \mathbf{b}$ were fully characterized by ${ }^{1} \mathrm{H}$ and ${ }^{13} \mathrm{C}$ NMR, IR, MS and elemental analysis. Thus, imines derived from aryl-, alkyl-, and alkenyl-substituted amino esters have been successfully applied in the ester enolate-imine condensation reaction.

\section{Discussion}

Configurational Stability. Previous studies with phenylglycine imine ester $\mathbf{2 a}$ (titanium-mediated coupling with a silyl ketene acetal ${ }^{22}$ or hetero-Diels-Alder reaction with an activated diene ${ }^{35}$ ) indicated that (partial) racemization of the chiral auxiliary was unavoidable, resulting in low asymmetric induction. However, we have demonstrated that $(R)$-phenylglycine can be used as the chiral auxiliary in the ester enolate-imine condensation reaction with excellent asymmetric induction. This procedure is applicable to other $\alpha$-amino acids also. Whereas imine ester $2 \mathrm{a}$ racemizes in THF solution, containing $\mathrm{NEt}_{3},\left(t_{1 / 2}=3 \mathrm{~min}\right.$, determined by decrease

(32) Turner, E. E.; Harris, M. M. Quart. Rev. 1947, 1, 299

(33) Nefkens, G. H. L.; Tesser, G. I.; Nivard, R. J. F. Recl. Trav. Chim. Pays-Bas 1960, 79, 688-698.

(34) For deprotection of 3-phthalimido $\beta$-lactams, see: (a) Kukolja S.; Lammert, S. R. J. Am. Chem. Soc. 1975, 97, 5582-5583. (b) Lammert, S. R.; Kukolja, S. J. Am. Chem. Soc. 1975, 97, 5583-5584. (c) Sasaki, T.; Minamoto, K.; Itoh, H. J. Org. Chem. 1978, 43, 23202325. (d) Osby, J. O.; Martin, M. G.; Ganem, B. Tetrahedron Lett. 1984 25, 2093-2096. (e) Motawia, M. S.; Wengel, J.; Abdel-Megid, A. E.; Pedersen, E. Synthesis 1989, 384-387.

(35) Waldmann, H. Angew. Chem. 1988, 100, 307-308.
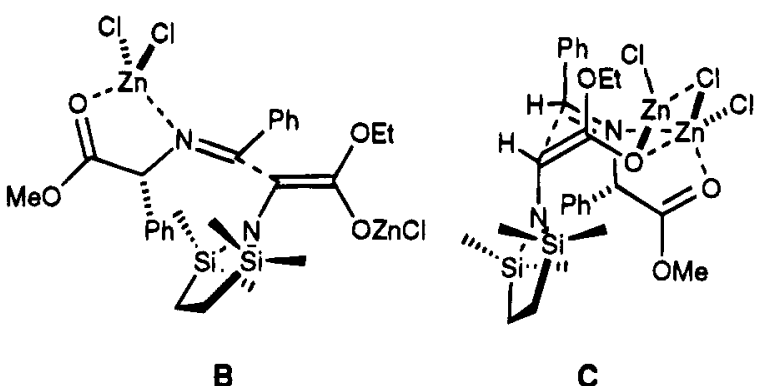

of optical rotation), imine esters $2 b$ and $2 c$ derived from $(R)$-(1,4-cyclohexadienyl)glycine, and $2 \mathbf{d}$, derived from $(S)$-valine, do not racemize when exposed to alkaline conditions.

The low configurational stability of the phenylglycine fragment was advantageous in the purification procedure. Epimerization of the deprotected $\beta$-lactam $4 \mathbf{a}$ by treatment with a base yielded the crystalline $(\alpha S)$ diastereoisomer epi-4a. A crystal structure determination ${ }^{6 f}$ revealed that the absolute configuration of the two newly formed stereogenic centers is $(3 S, 4 S)$. Remarkably, under the reaction conditions $\mathrm{HN}(\mathrm{iPr})_{2}$ does not induce epimerization of $\beta$-lactam 3a, whereas the isolated $\beta$-lactam $4 a$ is readily epimerized by $\mathrm{NEt}_{3}$ in $\mathrm{CH}_{2} \mathrm{Cl}_{2}$. Presumably, in the reaction mixture epimerization is inhibited by coordination of the $\beta$-lactam to $\mathrm{ZnCl}_{2}$. However, epimerization might occur in the reaction mediated by $\mathrm{Me}_{2} \mathrm{Zn}$, which is a weaker Lewis acid than $\mathrm{ZnCl}_{2}$, as the de of $3 \mathbf{a}$ is decreased to $76 \%$ (Table 1, entry 2).

Reaction Mechanism. The stereoselectivity of the zinc-mediated ester enolate-imine reaction has been rationalized via a six-membered chair transition state $(\mathbf{A})$ (Scheme 4), similar to the transition state models for the related aldol reaction. ${ }^{36,37}$ Activation of the imine by complexation to the zinc enolate is thought to be an essential step. ${ }^{6 \mathrm{~d}}$ The present results show that imine esters derived from chiral $\alpha$-amino acids do not react with chlorozinc enolates without activation by coordination to $\mathrm{ZnCl}_{2}$.

Lewis acid complexes of $\alpha$-imine esters have been studied in several reactions, e.g. Diels-Alder reactions, ${ }^{35}$ 1,3-dipolar cycloadditions, ${ }^{38}$ and radical additions. ${ }^{39}$ These reactions have been discussed in terms of a template effect, ${ }^{22}$ via coordination of the imine nitrogen and carboxyl oxygen atoms to the Lewis acidic metal. The highly diastereoselective double activation reaction suggests that in this reaction the $\mathrm{ZnCl}_{2}$-complexed imine ester also acts as a template (Scheme 4). The si-face of the $(R)$-imine ester is shielded by the $\alpha$-substituent. Hence, the bulky zinc enolate attacks preferentially (de $>97 \%$ ) from the $r e$-face of the imine. In the case of $(S)$ valine, the re-face is shielded by the isopropyl group, so the reactions take place at the $s i$-face.

(36) For a comprehensive summary of aldol transition states, see: Denmark, S. E.; Henke, B. R. J. Am. Chem. Soc. 1991, 113, 21772194

(37) For a review on aldol chemistry, see: Evans, D. A.; Nelson, J. V.; Taber, T. R. Top. Stereochem. 1982, 13, 1-115.

(38) (a) Waldmann H. Braun M.J Org Chem, $1992,57,4444-$ 4451. (b) Waldman, H.; Braun, M. Gazz. Chim. Ital. 1991, 121, 277. (39) (a) Grigg, R.; Gunaratne, H. Q. N.; Sridharan, V. Tetrahedron 1987, 43, 5887-5898. (b) Barr, D. A.; Grigg, R.; Gunaratne, H. Q. N.; Kemp, J.; McMeekin, P.; Sridharan, V. Tetrahedron 1988, 44, 557570. (c) Barr, D. A.; Dorrity, M. J.; Grigg, R.; Malone, J. F.; Montgomery, J.; Rajviroongit, S.; Stevenson, P. Tetrahedron Lett. 1990, 31, $6569-6572$. 
The possibility of transfer of the enolate moiety to the complexed $\mathrm{ZnCl}_{2}$, generating a monomeric imine esterenolate complex, can be discarded when the reactions of the lithium and the chlorozinc enolates $1 \mathbf{a}$ and $\mathbf{1 b}$ are compared. Lithium enolate 1a is more efficient in transferring the enolate moiety to $\mathrm{ZnCl}_{2}$ than the chlorozinc enolate 1b. However, in the former case, the conversion is less than $25 \%$, vs $>75 \%$ for the latter reaction. The slow formation of the same trans-diastereoisomer in both reactions is due to transmetalation of lithium enolate 1a with uncomplexed $\mathrm{ZnCl}_{2}$. Notably, the lithium enolate itself is completely unreactive toward the $\mathrm{Me}_{2} \mathrm{Zn}$-activated imine ester.

In THF solution, the chlorozinc enolate $\mathbf{1 b}$ is present as a 93:7 equilibrium mixture of $(E)$ - and $(Z)$-enolates. ${ }^{6 c}$ We have previously rationalized that in highly diastereoselective reactions the trans- $\beta$-lactams are formed exclusively via reaction of the $(Z)$-enolate ${ }^{6 b, c, e}$ through transition state (A) (Scheme 4). The more abundant $(E)$ enolate is only reactive in reactions under kinetic control. The relatively slow reaction of the $\mathrm{ZnCl}_{2}$-complexed imine esters with chlorozinc enolate $\mathbf{1 b}$ (presumably under thermodynamic control) excludes the intermediacy of $(E)$ enolates. In this double activation reaction, the re-face approach of the enolate is controlled by steric interactions of the imine C-substituent and the bulky 1-aza-2,5disilacyclopentyl moiety. The steric hindrance in the transition state of the $\mathrm{C}-\mathrm{C}$ coupling reaction is minimized either by a linear arrangement (transition state B) or by a gauche arrangement (transition state C) of the two double bonds (Scheme 4). Transition state $\mathbf{C}$, leading to the observed $(3 S, 4 S)$-enantiomer, is probably stabilized by interaction of the two metal centers via bridging oxygen and/or chlorine atoms.

The (trimethylsilyl)ethynyl-substituted imine ester $\mathbf{2 e}$ displays a satisfactory reactivity, but a very poor diastereoselectivity (Table I, entry 10 ). The fact that starting compound $2 \mathrm{e}$ is obtained as an $(E)-(Z)$-mixture ${ }^{30}$ accounts for two of the four diastereoisomers of $\beta$-lactam 3e. Via transition state $\mathbf{B}$, the $(3 R, 4 R, \alpha S)$ trans- $\beta$-lactam is obtained, whereas a similar transition state of a $(Z)$-imine and a $(Z)$-enolate gives the $(3 R, 4 S, \alpha S)$ cis- $\beta$-lactam. The other two diastereoisomers cannot be a result of poor facial selectivity ( $c f$. the valine imine ester $\mathbf{2 d}$ ) or poor configurational stability. Therefore, other transition states might play a role in this reaction.

The $\mathrm{C}-\mathrm{C}$ coupling reaction of the zinc enolate $\mathbf{1 b}$ with the imine esters $2 \mathbf{a}-\mathbf{e}$ does not go to completion. The enolate is not present as a well defined species, but as a mixture of coordinated dimers and tetramers. The interaggregate equilibria are sensitive to Lewis bases and Lewis acids. Excess $\mathrm{ZnCl}_{2}$ decreases the diastereoselectivity and the rate of the reaction of enolate $\mathbf{1 b}$ with imines. ${ }^{6 \mathrm{~b}}$ As the coordination of the imine ester to $\mathrm{ZnCl}_{2}$ is an equilibrium reaction, some free $\mathrm{ZnCl}_{2}$ is present in the reaction mixture. In the double activation reaction, free $\mathrm{ZnCl}_{2}$ becomes incorporated in mixed aggregates with zinc enolates. Thus, $\mathrm{ZnCl}_{2}$ is taken away from the coordination equilibrium, resulting in an increasing amount of uncoordinated (and thus unreactive) imine ester, and in a growing amount of $\mathrm{ZnCl}_{2}$-complexed enolates. All these complexation reactions are equilibria, which might eventually shift to the side of the $\beta$-lactam, because the ring-closure is irreversible. However, concomitant decomposition of the enolate ${ }^{28}$ reduces the maximum yield. The addition of excess $\mathrm{ZnCl}_{2}$ to the reaction mixture in order to reduce the amount of uncomplexed imine ester is not an option, as this reduces the reactivity of the zinc enolate to a great extent.

The maximum yield depends on the thermodynamics of the coordination of the different imine esters $2 \mathbf{a}-\mathbf{e}$ to $\mathrm{ZnCl}_{2}$ and the reactivity of the $\mathrm{ZnCl}_{2}$-complexed imine esters. Two opposite temperature effects determine the optimal reaction temperature: at $-78{ }^{\circ} \mathrm{C}$ the $\mathrm{C}-\mathrm{C}$ coupling reaction is slow; at $-30^{\circ} \mathrm{C}$ the enolate is more reactive, but the coordination equilibrium is shifted to the free (and thus unreactive) ester and free $\mathrm{ZnCl}_{2}$. Moreover, at higher temperatures decomposition of the enolate becomes competitive.

\section{Conclusions}

Imine esters derived from $\alpha$-amino acids [2-( $N$-alky]ideneamino) esters] have been successfully used in the zinc-mediated ester enolate-imine condensation reaction. We have shown that the configuration of the stereogenic center of the chiral auxiliary completely controls the absolute stereochemistry of the two newly formed stereogenic centers. Imine esters derived from aryl-, alkyl-, and alkenyl-substituted $\alpha$-amino esters have been successfully applied in the ester enolate-imine condensation reaction. Thus, the reactions of the zinc enolate $\mathbf{1 b}$ of ethyl (2,2,5,5-tetramethyl-1-aza-2,5-disilacyclopentyl)acetate with imine esters afforded 1-[(methoxycarbonyl)alkyl]-2-azetidinones $\mathbf{3 a}-\mathbf{d}$ with excellent asymmetric induction, while $\beta$-lactam $3 \mathbf{e}$ was obtained as a mixture of all four diastereoisomers. Complexation of the imine ester to a suitable Lewis acid $\left(\mathrm{ZnCl}_{2}\right)$ prior to the addition of the enolate is essential. The excellent diastereoselectivity of the $\mathrm{C}-\mathrm{C}$ coupling reactions strongly suggests that a highly ordered transition state is operative. However, mechanistic details are obscured by the interplay of various aggregation and complexation equilibria.

The introduction of reactive functional groups at $\mathrm{N}$ and $\mathrm{C} 4$ of the $\beta$-lactam via the double activation route has been accomplished. An interesting chiral auxiliary in this reaction is 2-(1,4-cyclohexadienyl)glycine, giving a nitrogen-substituent that can be activated via ozonolysis. Imines derived from 3-(trimethylsilyl)propynal offer a promising entry to $\beta$-lactams that can be further functionalized at the 4-position.

\section{Experimental Section}

General Data. All synthetic manipulations with airsensitive reagents were carried out under a dry, inert $\mathrm{N}_{2}$ atmosphere using standard Schlenk techniques. Solvents were dried and distilled from $\mathrm{Na} /$ benzophenone prior to use. Diisopropylamine was distilled at atmospheric pressure and stored over molecular sieves ( $3 \AA$ ). Ethyl $(2,2,5,5$-tetramethyl1-aza-2,5-disilacyclopentyl)acetate, ${ }^{25}$ dry zinc chloride, ${ }^{6 \mathrm{~b}}$ amino acid esters, ${ }^{40}$ and imine esters $\mathbf{2 a}-\mathbf{f}^{41}$. were prepared according to literature procedures. ${ }^{1} \mathrm{H}$ and ${ }^{13} \mathrm{C}$ NMR spectra were recorded on a Bruker AC 200 and a Bruker AC 300 spectrometer in chloroform- $d$, benzene- $d_{6}$, toluene- $d_{8}$, or THF- $d_{8}$. All coupling constants are presented in hertz $(\mathrm{Hz})$. IR spectra were recorded on a Mattson Galaxy FTIR 5000 spectrometer. Mass spectra (EI, $70 \mathrm{eV}$ ) were recorded on a Unicam Automass GCMS system. Melting points and boiling points are uncorrected. Elemental analyses were performed by Dornis und

(40) Brenner, M.; Huber, W. Helv. Chim. Acta 1953, 36, 1109-1115 (41) Imine ester $2 \mathbf{a}$ was prepared from $(R)$-2-phenylglycine methyl ester by condensation with benzaldehyde according to literature methods: Duhamel, L.; Plaquevent, J.-C. Bull. Soc. Chim. Fr. 1982, II-75. 2b-f were prepared analogously. 
Kolbe Mikroanalytisches Laboratorium, Mülheim a/d Ruhr, Germany.

2-(R)-(1,4-Cyclohexadienyl)glycine Methyl Ester. An amount of $41.36 \mathrm{~g}$ (199 mmol) of the $\mathrm{HCl}$-salt of $2-(R)-1,4$ cyclohexadienylglycyl chloride was added in $1 \mathrm{~g}$ portions to $100 \mathrm{~mL}$ of methanol at $0^{\circ} \mathrm{C}$. This reaction mixture was stirred for $1 \mathrm{~h}$. After the methanol was completely evaporated in vacuo, the product was dissolved in $50 \mathrm{~mL}$ of aqueous $\mathrm{NH}_{3}$, which was extracted three times with $50 \mathrm{~mL}$ of $\mathrm{CH}_{2} \mathrm{Cl}_{2}$. The combined organic layers were washed with $50 \mathrm{~mL}$ of water dried on $\mathrm{MgSO}_{4}$, filtrated, and concentrated. Distillation yielded the amino acid ester as a colorless oil. Yield : 30.98 $\mathrm{g}(185 \mathrm{mmol}, 93 \%)$. Bp $86{ }^{\circ} \mathrm{C} / 0.2 \mathrm{mbar}$. $[\alpha]^{20}{ }_{\mathrm{D}}-136.1$ (c 6, benzene). ${ }^{1} \mathrm{H}$ NMR $\left(\mathrm{CDCl}_{3}\right) ; \delta 5.5-5.6(\mathrm{~m}, 3 \mathrm{H}) ; 3.86(\mathrm{~s}, 1 \mathrm{H})$; $3.60(\mathrm{~s}, 3 \mathrm{H}) ; 2.4-2.6(\mathrm{~m}, 4 \mathrm{H}) ; 1.59(\mathrm{~s}, 2 \mathrm{H}) .{ }^{13} \mathrm{C} \mathrm{NMR}\left(\mathrm{CDCl}_{3}\right)$ : $\delta 174.2,133.8,123.7,123.6,122.3,60.3,52.1,26.6,25.4$.

(R)-N-Benzylidene-2-(1,4-cyclohexadienyl)glycine Methyl Ester (2b). Imine ester $\mathbf{2 b}$ was obtained as a white solid by crystallization from $\mathrm{Et}_{2} \mathrm{O}$. Yield: $89 \%$. Mp $45{ }^{\circ} \mathrm{C}$. $[\alpha]^{20} \mathrm{D}$ $+109.4\left(c 0.8, \mathrm{C}_{6} \mathrm{H}_{6}\right)$. ${ }^{1} \mathrm{H}$ NMR $\left(\mathrm{CDCl}_{3}\right): \delta 8.26(\mathrm{~s}, 1 \mathrm{H}) ; 7.8$ $(\mathrm{m}, 2 \mathrm{H}) ; 7.4(\mathrm{~m}, 3 \mathrm{H}) ; 5.6-5.8(\mathrm{~m}, 3 \mathrm{H}) ; 4.51(\mathrm{~s}, 1 \mathrm{H}) ; 3.73(\mathrm{~s}$, $3 \mathrm{H}) ; 2.75$ (br, $4 \mathrm{H}) .{ }^{13} \mathrm{C} \mathrm{NMR}\left(\mathrm{CDCl}_{3}\right): \delta 171.4,163.5,135.7$, $132.6,131.2,128.7,128.6,124.0,123.5,78.6,52.3,26.7,26.4$ IR $\left(\mathrm{KBr}, \mathrm{cm}^{-1}\right): 1731(\mathrm{C}=\mathrm{O}), 1637(\mathrm{C}=\mathrm{N})$. Anal. Calcd for $\mathrm{C}_{16} \mathrm{H}_{17} \mathrm{NO}_{2}$ : C 75.27, H 6.71, N 5.49. Found: C 75.35, H 6.72, N 5.38 .

(R)-N-(4-Methoxybenzylidene)-2-(1,4-cyclohexadienyl)glycine Methyl Ester (2c). Imine ester 2c was obtained as a white solid by crystallization from pentane. Yield: $92 \%$. Mp $49-50{ }^{\circ} \mathrm{C} .[\alpha]^{20} \mathrm{D}+125.0\left(\mathrm{c} 2\right.$, benzene). ${ }^{1} \mathrm{H} \mathrm{NMR}\left(\mathrm{CDCl}_{3}\right): \delta$ $8.21(\mathrm{~s}, 1 \mathrm{H}) ; 7.74(\mathrm{~d}, J=8.7,2 \mathrm{H}) ; 6.91(\mathrm{~d}, J=8.7,2 \mathrm{H}) ; 5.80$ (br, $1 \mathrm{H}) ; 5.68(\mathrm{~m}, 2 \mathrm{H}) ; 4.49(\mathrm{~s}, 1 \mathrm{H}) ; 3.82(\mathrm{~s}, 3 \mathrm{H}) ; 3.75(\mathrm{~s}, 3 \mathrm{H})$; $2.77(\mathrm{~m}, 4 \mathrm{H}) .{ }^{13} \mathrm{C}$ NMR $\left(\mathrm{CDCl}_{3}\right): \delta 171.6,162.6,162.0,132.7$, $130.3,128.7,124.0,123.5,123.3,113.9,78.5,55.4,52.3,26.7$, 26.4. IR $\left(\mathrm{KBr}, \mathrm{cm}^{-1}\right): 1737(\mathrm{C}=\mathrm{O}) ; 1638(\mathrm{C}=\mathrm{N})$. Anal. Calcd for $\mathrm{C}_{17} \mathrm{H}_{19} \mathrm{NO}_{3}$ : C 71.56, $\mathrm{H}$ 6.71, N 4.91. Found: C 71.70, $\mathrm{H}$ $6.78, \mathrm{~N} 5.01$

Methy] 2-[ $\boldsymbol{N}$-(4-Methoxybenzylidene)amino]-3-methylbutanoate (2d). Imine ester $2 \mathrm{~d}$ was obtained as a colorless oil after evaporation of all volatiles. Yield: $94 \%$. ${ }^{1} \mathrm{H}$ NMR $\left(\mathrm{CDCl}_{3}\right): \delta 8.16(\mathrm{~s}, 1 \mathrm{H}) ; 7.74(\mathrm{~d}, J=8.5,2 \mathrm{H}) ; 6.91(\mathrm{~d}, J=8.5$, $2 \mathrm{H}) ; 3.83(\mathrm{~s}, 3 \mathrm{H}) ; 3.73(\mathrm{~s}, 3 \mathrm{H}) ; 3.61(\mathrm{~d}, J=7.4,1 \mathrm{H}) ; 2.35(\mathrm{~d} \mathrm{sp}$, $J=7.4,6.7,1 \mathrm{H}) ; 0.93(\mathrm{~d}, J=6.7,6 \mathrm{H}) .{ }^{13} \mathrm{C} \mathrm{NMR}\left(\mathrm{CDCl}_{3}\right): \delta$ $172.7,162.5,161.9,130.2,128.7,113.9,80.5,55.4,51.9,31.7$, $19.5,18.7$.

Methyl 3-Methyl-2-[[3-(trimethylsilyl)-2-propynylidene]aminolbutanoate (2e). A solution of $2.91 \mathrm{~g}(29.6$ mmol) of (trimethylsilyl)acetylene in $20 \mathrm{~mL}$ of THF was cooled to $-30^{\circ} \mathrm{C}$. After addition of $29.0 \mathrm{mmol}$ of $n$-butyllithium $(18.2$ $\mathrm{mL}$ of a $1.6 \mathrm{M}$ solution in hexanes), the mixture was stirred for $45 \mathrm{~min}$ at this temperature. Next, $3.32 \mathrm{~g}(45 \mathrm{mmol})$ of dry DMF was added. The reaction mixture was stirred for $30 \mathrm{~min}$ at room temperature and then poured into $100 \mathrm{~mL}$ of $3 \mathrm{M} \mathrm{HCl}$ The $\mathrm{pH}$ was adjusted to 6 by addition of $15 \mathrm{~mL}$ of a saturated $\mathrm{NaHCO}_{3}$ solution, and the organic layer was separated, washed two times with $20 \mathrm{~mL}$ of water, and dried on $\mathrm{MgSO}_{4}$ After filtration, the yield of the aldehyde $(13.3 \mathrm{mmol}, 45 \%)$ was determined by integration of characteristic ${ }^{1} \mathrm{H}$ NMR signals. A solution of $1.45 \mathrm{~g}(11.0 \mathrm{mmol})$ of $(S)$-methyl 2-amino-3-methylbutanoate in $30 \mathrm{~mL}$ of $\mathrm{CH}_{2} \mathrm{Cl}_{2}$ was added, followed by $0.2 \mathrm{~g}$ of 4-toluenesulfonic acid and $20 \mathrm{~g}$ of $\mathrm{MgSO}_{4}$. After stirring for $30 \mathrm{~min}$, the reaction mixture was filtrated and concentrated in vacuo, affording imine ester $2 \mathrm{e}$ as a yellow oil. Yield: $2.21 \mathrm{~g}$ (9.3 mmol, 32\% based on (trimethylsilyl). acetylene. By ${ }^{1} \mathrm{H}$ NMR, it was shown that $2 e$ exists as a 65 : 35 mixture of $(E)$ - and $(Z)$-imine. $(E)$-Imine: ${ }^{1} \mathrm{H}$ NMR $\left(\mathrm{CDCl}_{3}\right): \delta 7.44(\mathrm{~s}, 1 \mathrm{H}) ; 3.72(\mathrm{~s}, 3 \mathrm{H}) ; 3.52(\mathrm{~d}, J=7.4,1 \mathrm{H})$; 2.30 (d sp, $J=7.4,6.7,1 \mathrm{H}) ; 0.91,0.88(\mathrm{~d}, J=6.7,6 \mathrm{H}) ; 0.00$ $(\mathrm{s}, 9 \mathrm{H}) .{ }^{13} \mathrm{C} \mathrm{NMR}\left(\mathrm{CDCl}_{3}\right): \delta 171.4,147.2,100.8,96.2,80.8$, 52.1, 31.7, 19.3, 18.5, 0.0. (Z)-Imine: ${ }^{1} \mathrm{H}$ NMR $\left(\mathrm{CDCl}_{3}\right): \delta$ $7.63(\mathrm{~d}, J=1.2,1 \mathrm{H}) ; 4.42(\mathrm{dd}, J=7.7,1.2,1 \mathrm{H}) ; 3.73(\mathrm{~s}, 3 \mathrm{H})$ 2.30 (d sp, $J=7.7,6.7,1 \mathrm{H}) ; 0.93(\mathrm{~d}, J=6.7,6 \mathrm{H}) ; 0.00$ (s, 9H). ${ }^{13} \mathrm{C}$ NMR $\left(\mathrm{CDCl}_{3}\right): \delta 171.6,145.0,105.3,99.6,73.7,51.9,32.8$, 19.2, 18.3, 0.0. IR of $(E)$ - $(Z)$ mixture $\left(\mathrm{C}_{6} \mathrm{H}_{6}, \mathrm{~cm}^{-1}\right): 1747,1739$ $\left(\mathrm{CO}_{2} \mathrm{Me}\right), 1610(\mathrm{C}=\mathrm{N})$. Anal. Calcd for $\mathrm{C}_{12} \mathrm{H}_{21} \mathrm{NO}_{2} \mathrm{Si}$ : C 60.21 , H 8.84, N 5.85; found: C $60.24, \mathrm{H} 8.86$, N 5.93 .
General Procedure for the Double Activation with $\mathrm{ZnCl}_{2}$. At $-78{ }^{\circ} \mathrm{C}, 4.8 \mathrm{mmol}$ of $n$-butyllithium $(3.0 \mathrm{~mL}$ of a $1.6 \mathrm{M}$ solution in hexanes) was added to a solution of $0.49 \mathrm{~g}$ $(4.8 \mathrm{mmol})$ of diisopropylamine in $50 \mathrm{~mL}$ of THF. After stirring

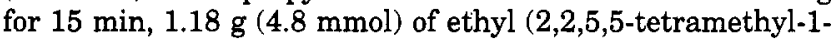
aza-2,5-disilacyclopentyl)acetate was added. The reaction mixture was stirred for an additional $15 \mathrm{~min}$, followed by addition of $4.8 \mathrm{mmol}$ of $\mathrm{ZnCl}_{2}(4.8 \mathrm{~mL}$ of a $1.0 \mathrm{M}$ solution in THF or $\left.\mathrm{Et}_{2} \mathrm{O}\right)$. At the same time $4.8 \mathrm{mmol}$ of $\mathrm{ZnCl}_{2}(4.8 \mathrm{~mL}$ of a $1.0 \mathrm{M}$ solution in THF or $\mathrm{Et}_{2} \mathrm{O}$ ) was added to a solution containing $4.8 \mathrm{mmol}$ of the appropriate imine ester in $10 \mathrm{~mL}$ of THF at $-78^{\circ} \mathrm{C}$. After stirring for $15 \mathrm{~min}$ at $-78^{\circ} \mathrm{C}$, this solution was added via a cannula to the solution containing the enolate. The reaction mixture was warmed to $-30^{\circ} \mathrm{C}$ over a $3 \mathrm{~h}$ period and kept at this temperature for $16 \mathrm{~h}$. After warming to room temperature, the solution was concentrated to $20 \mathrm{~mL}$, and $40 \mathrm{~mL}$ of $\mathrm{Et}_{2} \mathrm{O}$ was added. The reaction was quenched by the addition of $10 \mathrm{~mL}$ of a saturated $\mathrm{NH}_{4} \mathrm{Cl}$ solution. After the zinc salts were removed by filtration, the aqueous layer was separated and extracted three times with $10 \mathrm{~mL}$ of $\mathrm{Et}_{2} \mathrm{O}$. The organic layers were combined and dried over $\mathrm{MgSO}_{4}$. After filtration, the crude product was obtained by evaporation to dryness. Conversions based on consumed imine ester were determined by ${ }^{1} \mathrm{H}$ NMR.

trans-1-[(R)-(Methoxycarbonyl)(phenyl)methyl]-3-(S)(2,2,5,5-tetramethyl-1-aza-2,5-disilacyclopentyl)-4(S)-phenyl-2-azetidinone (3a). The crude product was obtained as a brown oil, which was shown by ${ }^{1} \mathrm{H}$ NMR to consist mainly of 3a $(\sim 70-80 \%)$ and the deprotected $\beta$-lactam $4 \mathbf{a}(0-10 \%)$. ${ }^{1} \mathrm{H}$ NMR $\left(\mathrm{CDCl}_{3}\right): \delta 7.1-7.3(\mathrm{~m}, 10 \mathrm{H}) ; 5.26(\mathrm{~s}, 1 \mathrm{H}) ; 4.14(\mathrm{~d}, J=$ $2.2,1 \mathrm{H}) ; 4.01(\mathrm{~d}, J=2.2,1 \mathrm{H}) ; 3.60(\mathrm{~s}, 3 \mathrm{H}) ; 0.6-0.7(\mathrm{~m}, 4 \mathrm{H})$; $-0.01,-0.09(\mathrm{~s}, 12 \mathrm{H}) .{ }^{13} \mathrm{C}$ NMR $\left(\mathrm{CDCl}_{3}\right): \delta 170.9,169.3$, $137.4,132.9,129.4,128.6,128.4,128.2,127.8,71.8,67.6,59.7$, $52.5,8.0,0.6,0.2$.

trans-1-[(R)-(1,4-Cyclohexadienyl)(methoxycarbonyl)methyl]-3(S)-(2,2,5,5-tetramethyl-1-aza-2,5-disilacyclopentyl)-4(S)-phenyl-2-azetidinone (3b). The product was obtained as a brown oil, which was shown by ${ }^{1} \mathrm{H}$ NMR to consist predominantly $(\sim 70 \%)$ of 3 b. ${ }^{1} \mathrm{H} \mathrm{NMR}\left(\mathrm{CDCl}_{3}\right): \delta 7.2-$ $7.3(\mathrm{~m}, 5 \mathrm{H}) ; 5.6(\mathrm{~m}, 3 \mathrm{H}) ; 4.42(\mathrm{~s}, 1 \mathrm{H}) ; 4.27(\mathrm{~d}, J=2.2,1 \mathrm{H})$; $4.14(\mathrm{~d}, J=2.2,1 \mathrm{H}) ; 3.60(\mathrm{~s}, 3 \mathrm{H}) ; 2.66(\mathrm{br}, 4 \mathrm{H}) ; 0.7(\mathrm{~m}, 4 \mathrm{H})$; $0.11,-0.01(\mathrm{~s}, 12 \mathrm{H}) .{ }^{13} \mathrm{C} \mathrm{NMR}\left(\mathrm{CDCl}_{3}\right): \delta 170.5,169.0,137.4$, $128.6,128.4,127.1,128.2,127.3,123.6,123.1,71.7,67.6,61.6$, 52.2, 27.6, 26.7, 8.0, 0.6, 0.3. IR $\left(\mathrm{C}_{6} \mathrm{H}_{6}, \mathrm{~cm}^{-1}\right): 1766\left(\mathrm{CO}_{2} \mathrm{Me}\right)$; $1750(\mathrm{NC}=\mathrm{O})$.

trans-1-[(R)-(1,4-Cyclohexadienyl)(methoxycarbonyl)methyl]-3(S)-(2,2,5,5-tetramethyl-1-aza-2,5-disilacyclopentyl)-4(S)-(4-methoxyphenyl)-2-azetidinone (3c). The product was obtained as a yellow oil, which was shown by ${ }^{1} \mathrm{H}$ NMR to consist for $\sim 60 \%$ of 3 c. ${ }^{1} \mathrm{H}$ NMR $\left(\mathrm{CDCl}_{3}\right): \delta 7.21$ (d, $J=8.6,2 \mathrm{H}) ; 6.87(\mathrm{~d}, J=8.6,2 \mathrm{H}) ; 5.55-5.68(\mathrm{~m}, 3 \mathrm{H}) ; 4.41(\mathrm{~s}$, $1 \mathrm{H}) ; 4.22(\mathrm{~d}, J=1.9,1 \mathrm{H}) ; 4.13(\mathrm{~d}, J=1.9,1 \mathrm{H}) ; 3.81(\mathrm{~s}, 3 \mathrm{H})$; $3.62(\mathrm{~s}, 3 \mathrm{H}) ; 2.6-2.8(\mathrm{~m}, 4 \mathrm{H}) ; 0.67-0.75(\mathrm{~m}, 4 \mathrm{H}) ; 0.11,0.00$ $(\mathrm{s}, 12 \mathrm{H}) .{ }^{13} \mathrm{C} \mathrm{NMR}\left(\mathrm{CDCl}_{3}\right): \delta 170.5,169.1,159.6,130.2,129.1$, $128.4,127.3,123.7,123.1,113.9,71.4,67.2,61.4,55.2,52.3$, 27.6, 26.7, 8.0, 0.7, 0.3.

trans-1-[(S)-1-(Methoxycarbonyl)-2-methylpropyl]-4(R)-(4-methoxyphenyl)-3-(2,2,5,5-tetramethyl-1-aza-2,5disilacyclopentyl)-2-azetidinone (3d). The purity of the product, that was obtained as a brown oil, was shown by ${ }^{1} \mathrm{H}$ NMR to be $\sim 40 \%$. ${ }^{1} \mathrm{H} \mathrm{NMR}\left(\mathrm{CDCl}_{3}\right): \delta 7.16(\mathrm{~d}, J=8.7,2 \mathrm{H})$; $6.89(\mathrm{~d}, J=8.7,2 \mathrm{H}) ; 4.16,4.09(\mathrm{~d}, J=2.1,2 \mathrm{H}) ; 3.82(\mathrm{~s}, 3 \mathrm{H})$; $3.63(\mathrm{~s}, 3 \mathrm{H}) ; 2.7(\mathrm{~m}, 1 \mathrm{H}) ; 1.08,0.96(\mathrm{~d}, J=6.7,6 \mathrm{H}) ; 0.7(\mathrm{~m}$, $4 \mathrm{H}) ; 0.15,0.01(\mathrm{~s}, 12 \mathrm{H})$.

1-[(S)-1-(Methoxycarbonyl)-2-methylpropyl]-3-(2,2,5,5tetramethyl-1-aza-2,5-disilacyclopentyl)-4-[(trimethylsilyl)ethynyl]-2-azetidinone (3e). The product was obtained as a brown oil. The presence of unidentified side products precluded a complete assignment of the ${ }^{1} \mathrm{H}$ NMR spectrum. Characteristic NMR-signals: Major trans-diastereoisomer: ${ }^{1} \mathrm{H}$ NMR $\left(\mathrm{CDCl}_{3}\right)$ : $\delta 4.30(\mathrm{~d}, J=2.2) ; 3.78(\mathrm{~d}, J=2.2)$; $3.72(\mathrm{~s}) ; 0.16(\mathrm{~s})$. Minor trans-diastereoisomer: ${ }^{1} \mathrm{H}$ NMR $\left(\mathrm{CDCl}_{3}\right): \delta 4.33(\mathrm{~d}, J=2.2) ; 3.97(\mathrm{~d}, J=2.2) ; 3.71(\mathrm{~s}) ; 0.13(\mathrm{~s})$.

General Procedure for the Removal of the Protecting Silyl Moiety. Deprotection was accomplished by stirring the crude product dissolved in $15 \mathrm{~mL}$ of THF with $10 \mathrm{~mL}$ of $1 \mathrm{M}$ 
$\mathrm{HCl}$. After $30 \mathrm{~min}$ the aqueous layer was separated and washed with $\mathrm{Et}_{2} \mathrm{O}(3 \times 10 \mathrm{~mL})$. By addition of aqueous ammonia the $\mathrm{pH}$ of the solution was adjusted to 10 . Extraction with $\mathrm{CH}_{2} \mathrm{Cl}_{2}$ (three times), drying on $\mathrm{MgSO}_{4}$, filtration, and finally evaporation to dryness afforded the deprotected product.

trans-3(S)-Amino-1-[(R)-(methoxycarbonyl)(phenyl)methyl]-4(S)-phenyl-2-azetidinone (4a). The product was obtained as a viscous yellow oil. Overall yield (starting from imine ester 2a): $72 \%$. ${ }^{1} \mathrm{H}$ NMR $\left(\mathrm{CDCl}_{3}\right): \delta 6.9-7.3(\mathrm{~m}, 10 \mathrm{H})$; $5.23(\mathrm{~s}, 1 \mathrm{H}) ; 4.06(\mathrm{~d}, J=2.2,1 \mathrm{H}) ; 3.97(\mathrm{~d}, J=2.2,1 \mathrm{H}) ; 3.60$ $(\mathrm{s}, 3 \mathrm{H}) ; 1.73(\mathrm{~s}, 2 \mathrm{H}) .{ }^{13} \mathrm{C} \mathrm{NMR}\left(\mathrm{CDCl}_{3}\right): \delta 171.2,169.3,137.2$, $132.8,129.1,128.6,128.5,128.3,128.0,126.4,69.1,67.3,60.0$, 52.6. IR $\left(\mathrm{KBr}, \mathrm{cm}^{-1}\right): 1763\left(\mathrm{CO}_{2} \mathrm{Me}\right) ; 1745(\mathrm{NC}=0)$.

trans-3(S)-Amino-1-[(R)-(1,4-cyclohexadienyl)(methoxycarbonyl)methyl]-4(S)-phenyl-2-azetidinone (4b). The product was obtained as a viscous yellow oil. By ${ }^{1} \mathrm{H}$ NMR it was shown that the product contained unreacted material $(1,4-$ cyclohexadienyl)glycine methyl ester. ${ }^{1} \mathrm{H}$ NMR $\left(\mathrm{CDCl}_{3}\right): \delta$ $7.2-7.3(\mathrm{~m}, 5 \mathrm{H}) ; 5.6-5.7(\mathrm{~m}, 3 \mathrm{H}) ; 4.46(\mathrm{~s}, 1 \mathrm{H}) ; 4.26(\mathrm{~d}, J=$ $2.2,1 \mathrm{H}) ; 3.97(\mathrm{~d}, J=2.2,1 \mathrm{H}) ; 3.57(\mathrm{~s}, 3 \mathrm{H}) ; 2.66(\mathrm{br}, 4 \mathrm{H}) ; 2.11$ $(\mathrm{s}, 2 \mathrm{H}) .{ }^{13} \mathrm{C} \mathrm{NMR}\left(\mathrm{CDCl}_{3}\right): \delta 171.2,168.8,137.4,128.7,128.5$, $128.1,126.9,123.6,123.2,69.3,67.5,61.6,52.3,27.5,26.7$. IR $\left(\mathrm{C}_{6} \mathrm{H}_{6}, \mathrm{~cm}^{-1}\right): 3397,3333\left(\mathrm{NH}_{2}\right), 2822\left(\mathrm{OCH}_{3}\right), 1768\left(\mathrm{CO}_{2} \mathrm{Me}\right)$, $1746(\mathrm{NC}=\mathrm{O})$.

trans-3(S)-Amino-1-[(R)-(1,4-cyclohexadienyl)(methoxycarbonyl)methyl]-4(S)-(4-methoxyphenyl)-2-azetidinone (4c). The product was obtained as a viscous yellow oil, which was shown to contain unreacted (1,4-cyclohexadienyl)glycine methyl ester. ${ }^{1} \mathrm{H}$ NMR $\left(\mathrm{CDCl}_{3}\right): \delta 7.21(\mathrm{~d}, J=$ $8.6,2 \mathrm{H}) ; 6.83(\mathrm{~d}, J=8.6,2 \mathrm{H}) ; 5.5-5.6(\mathrm{~m}, 3 \mathrm{H}) ; 4.41(\mathrm{~s}, 1 \mathrm{H})$; $4.12(\mathrm{~d}, J=1.9,1 \mathrm{H}) ; 3.89(\mathrm{~d}, J=1.9,1 \mathrm{H}) ; 3.74(\mathrm{~s}, 3 \mathrm{H}) ; 3.54$ $(\mathrm{s}, 3 \mathrm{H}) ; 2.61-2.69(\mathrm{~m}, 4 \mathrm{H}) ; 1.75$ (br.s, $2 \mathrm{H}) .{ }^{13} \mathrm{C} \mathrm{NMR}\left(\mathrm{CDCl}_{3}\right)$ : $\delta 171.2,168.8,159.7,129.2,128.2,128.1,126.6,123.5,123.1$, $113.9,69.1,66.9,61.3,55.2,52.2,27.4,26.6$.

trans-3(R)-Amino-1-[(S)-1-(methoxycarbonyl)-2-methylpropyl]-4(R)-(4-methoxyphenyl)-2-azetidinone (4d): yellow oil. The purity of the product was shown by ${ }^{1} \mathrm{H}$ NMR to be $>90 \%$. Yield starting from the imine ester $2 \mathrm{~d}: 0.98 \mathrm{~g}(3.2$ mmol, $37 \%) .{ }^{1} \mathrm{H} \mathrm{NMR}\left(\mathrm{CDCl}_{3}\right): \delta 7.20(\mathrm{~d}, J=8.7,2 \mathrm{H}) ; 6.88$ $(\mathrm{d}, J=8.7,2 \mathrm{H}) ; 4.15(\mathrm{~d}, J=1.9,1 \mathrm{H}) ; 3.97(\mathrm{~d}, J=1.9,1 \mathrm{H})$; $3.80(\mathrm{~s}, 3 \mathrm{H}) ; 3.58(\mathrm{~d}, J=9.5,1 \mathrm{H}) ; 3.52(\mathrm{~s}, 3 \mathrm{H}) ; 2.54(\mathrm{~m}, 1 \mathrm{H})$; $1.86(\mathrm{br} \mathrm{s}, 2 \mathrm{H}) ; 1.08,0.90(\mathrm{~d}, J=6.7,6 \mathrm{H}) .{ }^{13} \mathrm{C} \mathrm{NMR}\left(\mathrm{CDCl}_{3}\right)$ : $\delta 170.9,169.6,159.9,128.6,128.1,114.1,69.2,66.1,62.8,55.3$, $52.0,28.4,20.1,19.5$.

3-Amino-1-[(S)-1-(methoxycarbonyl)-2-methylpropyl]4-[(trimethylsilyl)ethynyl]-2-azetidinone (4e): brownish yellow oil. The purity of the product was shown by ${ }^{1} \mathrm{H}$ NMR to be $68 \%$. Major trans-diastereoisomer: ${ }^{1} \mathrm{H}$ NMR $\left(\mathrm{CDCl}_{3}\right): \delta 4.18(\mathrm{~d}, J=2.0,1 \mathrm{H}) ; 3.88(\mathrm{~d}, J=2.0,1 \mathrm{H}) ; 3.78(\mathrm{~d}$, $J=8.4,1 \mathrm{H}) ; 3.73(\mathrm{~s}, 3 \mathrm{H}) ; 2.55(\mathrm{~m}, 1 \mathrm{H}) ; 1.0-1.2(\mathrm{~d}, 6 \mathrm{H}) ; 0.15$ (s). Minor trans-diastereoisomer: ${ }^{1} \mathrm{H}$ NMR $\left(\mathrm{CDCl}_{3}\right)$ : ${ }^{1} \mathrm{H}$ $\mathrm{NMR}\left(\mathrm{CDCl}_{3}\right): \delta 4.22(\mathrm{~d}, 1 \mathrm{H}) ; 4.2(\mathrm{~s}) ; 3.73(\mathrm{~s}, 3 \mathrm{H}) ; 2.5(\mathrm{~m}, 1 \mathrm{H})$; $1.0-1.2(\mathrm{~d}, 6 \mathrm{H}) ; 0.16(\mathrm{~s})$. Major cis-diastereoisomer: ${ }^{1} \mathrm{H}$ NMR $\left(\mathrm{CDCl}_{3}\right): \delta 4.73(\mathrm{~d}, J=5.1,1 \mathrm{H}) ; 4.33(\mathrm{~d}, J=5.1,1 \mathrm{H})$; $4.2(\mathrm{~s}) ; 3.71(\mathrm{~s}, 3 \mathrm{H}) ; 2.4(\mathrm{~m}, 1 \mathrm{H}) ; 1.0-1.2(\mathrm{~d}, 6 \mathrm{H}) ; 0.18(\mathrm{~s})$. Minor cis-diastereoisomer: ${ }^{1} \mathrm{H}$ NMR $\left(\mathrm{CDCl}_{3}\right): \delta 4.43(\mathrm{~d}, J$ $=5.0,1 \mathrm{H}) ; 4.31(\mathrm{~d}, J=5.0,1 \mathrm{H}) ; 3.71(\mathrm{~s}, 3 \mathrm{H}) ; 2.4(\mathrm{~m}, 1 \mathrm{H})$; $1.0-1.2(\mathrm{~d}, 6 \mathrm{H}) ; 0.14(\mathrm{~s})$.

trans-3(S)-Amino-1-[(S)-(methoxycarbonyl)(phenyl)methyl]-4(S)-phenyl-2-azetidinone (epi-4a). A solution of $2.0 \mathrm{mmol}$ of $4 \mathrm{a}$ in $10 \mathrm{~mL}$ of $\mathrm{CH}_{2} \mathrm{Cl}_{2}$ was stirred for $30 \mathrm{~min}$ with $10 \mathrm{~mL}$ of aqueous ammonia. The organic layer was separated, dried on $\mathrm{MgSO}_{4}$, filtrated, and concentrated, yielding a 1:1 mixture of the two epimers as a faintly yellow oil. Upon addition of $\mathrm{Et}_{2} \mathrm{O}$, epi-4a precipitated as a white solid, that was purified by crystallization from THF at $-30^{\circ} \mathrm{C}$. Yield: $39 \%$. The remaining $61 \%$ was recovered and again epimerized, affording another $16 \%$ of epi-4a in the next crystallization. Mp $165^{\circ} \mathrm{C} .[\alpha]^{20} \mathrm{D}=+132.1(c=2$, benzene). ${ }^{1} \mathrm{H}$ NMR $\left(\mathrm{CDCl}_{3}\right): \delta 6.9-7.3(\mathrm{~m}, 10 \mathrm{H}) ; 5.41(\mathrm{~s}, 1 \mathrm{H}) ; 4.56(\mathrm{~d}, J$ $=2.0,1 \mathrm{H}) ; 3.91(\mathrm{~d}, J=2.0,1 \mathrm{H}) ; 3.74(\mathrm{~s}, 3 \mathrm{H}) ; 1.73(\mathrm{~s}, 2 \mathrm{H}) .{ }^{13} \mathrm{C}$ NMR $\left(\mathrm{CDCl}_{3}\right): \delta 171.2,169.8,137.2,133.4,128.7,128.7,128.5$, $128.3,127.9,126.4,69.9,66.8,58.6,52.7$. IR $\left(\mathrm{KBr}, \mathrm{cm}^{-1}\right): 1755$ $\left(\mathrm{CO}_{2} \mathrm{Me}\right) ; 1739(\mathrm{NC}=\mathrm{O})$. MS: $m / z=310(1.4 \%), 254(100 \%)$.
Anal. Calcd for $\mathrm{C}_{18} \mathrm{H}_{18} \mathrm{~N}_{2} \mathrm{O}_{3}: \mathrm{C} 69.66, \mathrm{H}$ 5.85, N 9.03. Found: C $69.52, \mathrm{H} 5.78, \mathrm{~N} 8.97$.

trans-1-[(S)-(Methoxycarbonyl)(phenyl)methyl]-4(S)phenyl-3(S)-(2,2,5,5-tetramethyl-1-aza-2,5-disilacyclopentyl)-2-azetidinone (epi-3a). A solution of $0.25 \mathrm{~g}(1.0 \mathrm{mmol})$ of 1,2 -bis(chlorodimethylsilyl)ethane in $10 \mathrm{~mL}$ of $\mathrm{CH}_{2} \mathrm{Cl}_{2}$ was added dropwise $(30 \mathrm{~min})$ to a cooled $\left(0^{\circ} \mathrm{C}\right)$ solution of $0.31 \mathrm{~g}$ $(1.0 \mathrm{mmol})$ of epi-4a and $3.0 \mathrm{mmol}$ of $\mathrm{NEt}_{3}$ in $20 \mathrm{~mL}$ of $\mathrm{CH}_{2^{-}}$ $\mathrm{Cl}_{2}$. The reaction mixture was stirred for $2 \mathrm{~h}$ at $0^{\circ} \mathrm{C}$ and for $16 \mathrm{~h}$ at room temperature. After addition of $20 \mathrm{~mL}$ of pentane, the salts were removed by filtration. All volatiles were removed in vacuo, affording a 44:56 mixture of 3a and epi-3a as a yellow oil. Yield: $0.40 \mathrm{~g}(88 \%)$. ${ }^{1} \mathrm{H} \mathrm{NMR}\left(\mathrm{CDCl}_{3}\right): \delta 6.9-$ $7.3(\mathrm{~m}, 10 \mathrm{H}) ; 5.30(\mathrm{~s}, 1 \mathrm{H}) ; 4.53(\mathrm{~d}, J=2.0,1 \mathrm{H}) ; 4.13(\mathrm{~d}, J=$ $2.0,1 \mathrm{H}) ; 3.72(\mathrm{~s}, 3 \mathrm{H}) ; 0.6-0.7(\mathrm{~m}, 4 \mathrm{H}) ; 0.10,-0.03(\mathrm{~s}, 12 \mathrm{H})$. ${ }^{13} \mathrm{C} \mathrm{NMR}\left(\mathrm{CDCl}_{3}\right): \delta 170.2,169.4,137.3,133.3,128.80,128.74$, $128.68,128.4,127.2,126.7,72.4,67.3,58.4,52.3,8.0,0.5,0.2$.

General Procedure for the Introduction of the Phthalimido Moiety. A solution of $0.38 \mathrm{~g}(2.5 \mathrm{mmol})$ of phthalic anhydride and $2.0 \mathrm{mmol}$ of the appropriate 3 -amino $\beta$-lactam in $100 \mathrm{~mL}$ of benzene was refluxed for $16 \mathrm{~h}$ with azeotropic removal of water. The solution was concentrated to $10 \mathrm{~mL}$, cooled to room temperature, filtered, and evaporated until dryness. After trituration with pentane, the crude phthalimido $\beta$-lactam was dried in vacuo. Purification was performed by a combination of column chromatography and crystallization.

trans-1-[(R)-(1,4-Cyclohexadienyl)(methoxycarbonyl)methyl]-4(S)-phenyl-3(S)-phthalimido-2-azetidinone (5b). Starting from $\mathbf{4 b}, \mathbf{5 b}$ was obtained as a white solid by column chromatography $\left(\mathrm{SiO}_{2}\right.$, hexane/EtOAc $\left.50: 50\right)$, followed by crystallization from $\mathrm{Et}_{2} \mathrm{O}$. Yield: $0.33 \mathrm{~g}$ (37\% based on $2 \mathrm{~b}$ ). Mp: $174-175{ }^{\circ} \mathrm{C}$. $[\alpha]^{20} \mathrm{D}-336.9$ (c 0.4 , benzene). ${ }^{1} \mathrm{H}$ NMR $\left(\mathrm{CDCl}_{3}\right): \delta 7.84(\mathrm{~m}, 2 \mathrm{H}) ; 7.76(\mathrm{~m}, 2 \mathrm{H}) ; 7.3-7.5(\mathrm{~m}, 5 \mathrm{H}) ; 5.5-$ $5.7(\mathrm{~m}, 3 \mathrm{H}) ; 5.29(\mathrm{~d}, J=2.6,1 \mathrm{H}) ; 5.01(\mathrm{~d}, J=2.6,1 \mathrm{H}) ; 4.84$ $(\mathrm{s}, 1 \mathrm{H}) ; 3.63(\mathrm{~s}, 3 \mathrm{H}) ; 2.6-2.9(\mathrm{~m}, 4 \mathrm{H}) .{ }^{13} \mathrm{C} \mathrm{NMR}: \delta 168.8,166.8$, $165.7,136.3,134.5,131.7,129.0,128.7,127.7,127.5,127.3$, $123.8,123.1,61.6,61.5,60.9,52.3,27.9,26.7 . \mathrm{IR}\left(\mathrm{KBr}, \mathrm{cm}^{-1}\right)$ : $1767\left(\mathrm{CO}_{2} \mathrm{Me}\right) ; 1742(\mathrm{NC}=\mathrm{O}) ; 1729$ (CO-N-CO). MS: $\mathrm{m} / \mathrm{z}=$ $442,249(100 \%)$. Anal. Calcd for $\mathrm{C}_{26} \mathrm{H}_{22} \mathrm{~N}_{2} \mathrm{O}_{5}$ : C 70.58, $\mathrm{H} 5.01$, N 6.33. Found: C 70.64, H 4.96, N 6.29.

trans-1-[(R)-(1,4-Cyclohexadienyl)(methoxycarbonyl)methyl]-4(S)-(4-methoxyphenyl)-3(S)-phthalimido-2azetidinone $(\mathbf{5 c})$. Column chromatography $\left(\mathrm{SiO}_{2}\right.$, hexane/ EtOAc 50:50) afforded crude 5c as a white solid, contaminated by the dehydrogenated compound. Crystallization did not result in further purification. ${ }^{1} \mathrm{H} \mathrm{NMR}\left(\mathrm{CDCl}_{3}\right): \delta 7.84(\mathrm{~m}$, $2 \mathrm{H}) ; 7.73(\mathrm{~m}, 2 \mathrm{H}) ; 7.35(\mathrm{~d}, J=8.7,2 \mathrm{H}) ; 6.89(\mathrm{~d}, J=8.6,2 \mathrm{H})$; $5.52-5.69(\mathrm{~m}, 3 \mathrm{H}) ; 5.26(\mathrm{~d}, J=2.6,1 \mathrm{H}) ; 4.96(\mathrm{~d}, J=2.6,1 \mathrm{H})$; $4.83(\mathrm{~s}, 1 \mathrm{H}) ; 3.81(\mathrm{~s}, 3 \mathrm{H}) ; 3.64(\mathrm{~s}, 3 \mathrm{H}) ; 2.5-2.9(\mathrm{~m}, 4 \mathrm{H}) .{ }^{13} \mathrm{C}$ NMR: $\delta 168.9,166.9,165.7,160.1,134.5,131.7,128.9,128.1$, $127.7,127.2,123.7,123.1,114.0,61.6,61.1,60.7,55.3,52.4$, 27.9, 26.7. MS: $m / z=279(100 \%)$.

1-[(S)-1-(Methoxycarbonyl)-2-methylpropyl]]-4(R)-(4methoxyphenyl)-3(R)-phthalimido-2-azetidinone (5d). Column chromatography $\left(\mathrm{SiO}_{2}\right.$, hexane/EtOAc 50:50) afforded pure $5 \mathrm{~d}$ as an off-white foam. Yield: $0.58 \mathrm{~g}(25 \%$ based on 2d). Mp $66{ }^{\circ} \mathrm{C}$. $[\alpha]^{20} \mathrm{D}+261$ (c 0.6 , benzene). ${ }^{1} \mathrm{H}$ NMR $\left(\mathrm{CDCl}_{3}\right): \delta 7.86(\mathrm{~m}, 2 \mathrm{H}) ; 7.74(\mathrm{~m}, 2 \mathrm{H}) ; 7.28(\mathrm{~d}, J=7.7,2 \mathrm{H})$; $6.91(\mathrm{~d}, J=7.7,2 \mathrm{H}) ; 5.27(\mathrm{~d}, J=2.7,1 \mathrm{H}) ; 5.00(\mathrm{~d}, J=2.7$, $1 \mathrm{H}) ; 3.82(\mathrm{~s}, 3 \mathrm{H}) ; 3.68(\mathrm{~s}, J=9.8,1 \mathrm{H}) ; 3.64(\mathrm{~s}, 3 \mathrm{H}) ; 2.64(\mathrm{~m}$, $1 \mathrm{H}) ; 1.20,0.96(\mathrm{~d}, J=6.7,6 \mathrm{H}) .{ }^{13} \mathrm{C} \mathrm{NMR}\left(\mathrm{CDCl}_{3}\right): \delta 168.7$, $166.6,164.6,160.3,134.5,131.7,128.7,127.1,123.7,114.4$, $63.2,61.9,60.6,55.4,52.0,28.3,19.9,19.6$. IR $\left(\mathrm{KBr}, \mathrm{cm}^{-1}\right)$ : $1769\left(\mathrm{CO}_{2} \mathrm{Me}\right) ; 1743(\mathrm{NC}=\mathrm{O}) ; 1722(\mathrm{CO}-\mathrm{N}-\mathrm{CO})$. MS: $\mathrm{m} / \mathrm{z}$ $=436,279(100 \%)$. Anal. Calcd for $\mathrm{C}_{24} \mathrm{H}_{24} \mathrm{~N}_{2} \mathrm{O}_{6}: \mathrm{C} 66.04, \mathrm{H}$ 5.54, N 6.42. Found: C 65.88, H 5.45, N 6.43.

1-[(S)-1-(Methoxycarbonyl)-2-methylpropyl]-4-[(trimethylsilyl)ethynyl]-3-phthalimido-2-azetidinone (5e). Via column chromatography $\left(\mathrm{SiO}_{2}\right.$, hexane/EtOAc 60:40), a $2: 1$ diastereomeric mixture of $5 \mathbf{e}$ was obtained as an off-white foam. Crystallization from $\mathrm{Et}_{2} \mathrm{O}$ afforded a $1: 1$ mixture of $5 \mathbf{e}$ as colorless block-shaped crystals. Yield: $0.45 \mathrm{~g},(1.1 \mathrm{mmol}$ $21 \%$ based on 2e). Major trans-diastereoisomer: ${ }^{1} \mathrm{H}$ NMR $\left(\mathrm{CDCl}_{3}\right)$ : $\delta 7.86(\mathrm{~m}, 2 \mathrm{H}) ; 7.74(\mathrm{~m}, 2 \mathrm{H}) ; 5.41(\mathrm{~d}, J=2.7,1 \mathrm{H})$; $4.76(\mathrm{~d}, J=2.7,1 \mathrm{H}) ; 3.99(\mathrm{~d}, J=8.9,1 \mathrm{H}) ; 3.62(\mathrm{~s}, 3 \mathrm{H}) ; 2.60$ $(\mathrm{m}, 1 \mathrm{H}) ; 1.16,1.09(\mathrm{~d}, J=6.7,6 \mathrm{H}) ; 0.16(\mathrm{~s}, 9 \mathrm{H}) .{ }^{13} \mathrm{C} \mathrm{NMR}$ 
$\left(\mathrm{CDCl}_{3}\right): \delta 168.8,166.5,163.4,134.5,131.6,123.7,98.7,94.6$, $61.9,60.5, \quad 52.0,48.8,28.3,19.6,19.5,-0.5$. Minor trans-diastereoisomer: ${ }^{1} \mathrm{H} \mathrm{NMR}\left(\mathrm{CDCl}_{3}\right): \delta 7.86(\mathrm{~m}, 2 \mathrm{H})$; $7.74(\mathrm{~m}, 2 \mathrm{H}) ; 5.40(\mathrm{~d}, J=2.6,1 \mathrm{H}) ; 4.86(\mathrm{~d}, J=2.6,1 \mathrm{H}) ; 4.15$ $(\mathrm{d}, J=10.1,1 \mathrm{H}) ; 3.65(\mathrm{~s}, 3 \mathrm{H}) ; 2.56(\mathrm{~m}, 1 \mathrm{H}) ; 1.16,1.00(\mathrm{~d}, J=$ $6.7,6 \mathrm{H}) ; 0.15(\mathrm{~s}, 9 \mathrm{H}) .{ }^{13} \mathrm{C} \mathrm{NMR}\left(\mathrm{CDCl}_{3}\right): \delta 169.5,166.6,164.2$, 134.6, 134.5, 123.6, 99.9, 93.8, 62.2, 60.7, 52.1, 48.5, 28.5, 19.8, $19.3,-0.4$. IR of mixture $\left(\mathrm{KBr}, \mathrm{cm}^{-1}\right): 2183(\mathrm{C} . . \mathrm{C}) ; 1782,1770$ $\left(\mathrm{CO}_{2} \mathrm{Me}\right) ; 1732(\mathrm{NC}=\mathrm{O}), 1723(\mathrm{CO}-\mathrm{N}-\mathrm{CO})$. MS: $\mathrm{m} / z=426$ (5\%), $270(100 \%)$. Anal. Calcd for $\mathrm{C}_{22} \mathrm{H}_{26} \mathrm{~N}_{2} \mathrm{O}_{5} \mathrm{Si}: \mathrm{C} 61.95, \mathrm{H}$ 6.14, N 6.57, Si 6.59. Found: C 61.82, H 6.17, N 6.50, Si 6.74. Major cis-diastereoisomer: ${ }^{1} \mathrm{H}$ NMR $\left(\mathrm{CDCl}_{3}\right): \delta 7.86(\mathrm{~m}$, $2 \mathrm{H}) ; 7.74(\mathrm{~m}, 2 \mathrm{H}) ; 5.48(\mathrm{~d}, J=5.2,1 \mathrm{H}) ; 4.97(\mathrm{~d}, J=5.2,1 \mathrm{H})$; $4.38(\mathrm{~d}, J=8.9,1 \mathrm{H}) ; 3.74(\mathrm{~s}, 3 \mathrm{H}) ; 2.44(\mathrm{~m}, 1 \mathrm{H}) ; 1.22,1.04(\mathrm{~d}$, $J=6.7,6 \mathrm{H}) ;-0.16(\mathrm{~s}, 9 \mathrm{H}) .{ }^{13} \mathrm{C} \mathrm{NMR}\left(\mathrm{CDCl}_{3}\right): \delta 170.3,166.6$, 164.1, 134.4, 131.7, 123.6, 98.4, 95.4, 60.8, 58.3, 52.1, 49.9, 29.6, 19.7, 19.3, -1.0. Minor cis-diastereoisomer: ${ }^{1} \mathrm{H}$ NMR $\left(\mathrm{CDCl}_{3}\right): \delta 7.86(\mathrm{~m}, 2 \mathrm{H}) ; 7.74(\mathrm{~m}, 2 \mathrm{H}) ; 5.44(\mathrm{~d}, J=5.2,1 \mathrm{H})$; $4.55(\mathrm{~d}, J=2.6,1 \mathrm{H}) ; 3.81(\mathrm{~d}, J=8.9,1 \mathrm{H}) ; 3.76(\mathrm{~s}, 3 \mathrm{H}) ; 2.63$ $(\mathrm{m}, 1 \mathrm{H}) ; 1.18,1.05(\mathrm{~d}, J=6.7,6 \mathrm{H}) ;-0.17(\mathrm{~s}, 9 \mathrm{H}) .{ }^{13} \mathrm{C}$ NMR $\left(\mathrm{CDCl}_{3}\right): \delta 169.4,166.6,162.7,134.4,131.7,123.6,97.2,95.4$, $60.4,57.9,52.3,50.2,28.8,19.8,14.2,-0.9$.

trans $-1-[(R)-(1,4$-cyclohexadienyl)(methoxycarbonyl)methyl]-3(S)-[(methoxycarbonyl)amino]-4(S)-phenyl-2azetidinone (6b). A $1.86 \mathrm{~g}$ amount of the yellow oil contain- ing $4 \mathrm{~b}$ was dissolved in $40 \mathrm{~mL}$ of benzene, to which $0.94 \mathrm{~g}$ $(10.0 \mathrm{mmol})$ of methoxycarbonyl chloride was added. In 10 min a solution of $1.82 \mathrm{~g}(18 \mathrm{mmol})$ of $\mathrm{NEt}_{3}$ in $10 \mathrm{~mL}$ of benzene was added via a dropping funnel. After stirring overnight at room temperature, the precipitate was filtered off. The benzene solution was washed twice with $10 \mathrm{~mL}$ of $\mathrm{H}_{2} \mathrm{O}$, dried on $\mathrm{MgSO}_{4}$, filtered, and concentrated in vacuo, affording 2.19 $\mathrm{g}$ of a yellow foam. Column chromatography (EtOAc/hexane $1: 1$, silica) afforded $6 \mathrm{~b}$ as an off-white solid. Yield: $0.34 \mathrm{~g}(0.9$ mmol, 9\%). Mp: $38-42{ }^{\circ} \mathrm{C}$. $[\alpha]^{20} \mathrm{D}-161.4$ (c 1.3, benzene). ${ }^{1} \mathrm{H}$ NMR $\left(\mathrm{CDCl}_{3}\right): \delta 7.3-7.4(\mathrm{~m}, 5 \mathrm{H}) ; 5.6-5.7(\mathrm{~m}, 3 \mathrm{H}) ; 5.55$ (br d, $J=6.3,1 \mathrm{H}) ; 4.64(\mathrm{br}, 1 \mathrm{H}) ; 4.58(\mathrm{~s}, 1 \mathrm{H}) ; 4.45(\mathrm{~d}, J=$ $6.3,1 \mathrm{H}) ; 3.75(\mathrm{~s} ; 3 \mathrm{H}) ; 3.63(\mathrm{~s}, 3 \mathrm{H}) ; 2.69\left(\mathrm{br}, 4 \mathrm{H}_{2}\right) .{ }^{13} \mathrm{C} \mathrm{NMR}$ $\left(\mathrm{CDCl}_{3}\right): \delta 168.9,167.7,156.0,136.7,128.7,127.6,127.4,127.1$, 123.6, 123.1, 66.1, 64.1, 61.3, 52.6, 52.4, 27.7, 26.7. IR ( $\mathrm{KBr}$, $\left.\mathrm{cm}^{-1}\right): 2822\left(\mathrm{OCH}_{3}\right), 1767\left(\mathrm{CO}_{2} \mathrm{Me}\right) ; 1746(\mathrm{NC}=\mathrm{O}) ; 1728$ $\left(\mathrm{NCO}_{2}\right)$. Anal. Calcd for $\mathrm{C}_{20} \mathrm{H}_{22} \mathrm{~N}_{2} \mathrm{O}_{5}$ : C 64.85, H 5.99, N 7.56. Found: C 63.60, H 5.85, N 7.33.

Acknowledgment. The authors wish to thank Gistbrocades, Delft, The Netherlands, for financially supporting this research.

JO950116R 